\title{
KOMODIFIKASI DAN EFEK EKSTERNALITAS PROGRAM DAKWAHTAINMENT ISLAM ITU INDAH
}

\author{
Dedy Pradesa \\ STID Al-Hadid, Surabaya \\ depra19312@gmail.com
}

\author{
Yunda Presti Ardilla \\ UIN Sunan Ampel, Surabaya \\ yundaardilla@gmail.com
}

\begin{abstract}
Abstrak: Tulisan ini mengeksplorasi gejala komodifikasi dan efek eksternalitas dalam tayangan program dakwahtainment Islam Itu Indah Trans TV. Program tersebut memiliki rating tinggi dan mampu bertahan hingga tahun kesepuluh. Tayangan dakwahtainment di televisi komersil tentu tidak terlepas dari proses komodifikasi dan efek eksternalitas. Pijakan teori yang digunakan adalah teori komodifikasi menurut Vincent Mosco yang dilengkapi Idi Subandy Ibrahim dan Bachruddin Ali Akhmad, serta teori efek eksternalitas siaran televisi menurut Edward S. Herman. Metodologi studi adalah kualitatif dengan pendekatan analisis semiotik. Data dikumpulkan melalui dokumentasi dan observasi tayangan di televisi, media sosial YouTube, dan Instagram, dengan sampel 91 episode tayangan (Desember 2019Februari 2020). Analisis dilakukan dengan mengidentifikasi signifikasi struktur tanda dalam tayangan dakwahtainment meliputi (a) konten komunikasi seperti judul materi dakwah, klasifikasi pesan dakwah, tagline acara; (b) khalayak, terdiri dari jemaah di studio dan di rumah, serta tingkat rating, dan share program; (c) tenaga kerja, terkait pilihan dai sebagai narasumber, host, dan bintang tamu; (d) nilai-nilai agama yang diwakili substansi isi pesan dakwahnya. Hasil studi menunjukkan bahwa gejala komodifikasi terjadi dalam empat kategori yaitu komodifikasi konten komunikasi, khalayak, pengisi acara (tenaga kerja), dan nilai-nilai keagamaan. Efek eksternalitas yang dihasilkan ada yang bermuatan positif, namun lebih banyak muatan negatifnya.
\end{abstract}

Kata kunci: Dakwahtainment, Komodifikasi, Efek Eksternalitas

\begin{abstract}
This discourse explores commodification symptoms and the externalities effects in dakwahtainment broadcast titled Islam Itu Indah on TransTV. It has high ratings and continously airs until the tenth year. Dakwahtainment in commercial TV is inevitable from the process of commodification and externalities effects. It is based on Vincent Mosco's theory of commodification, completed by Idi Subandy Ibrahim and Bachruddin Ali Akhmad, and Erdward S. Herman's theory of externalities effects on television broadcast. It applies qualitative methodology with semiotic analysis approach. Data were from documentation and observation on TV broadcasts, Youtube and Instagram, with a sample of 91 episodes (December 2019 - February 2020). The analysis is conducted by identifying significance of sign structure in dakwahtainment, including : (a) communication content, such as da'wah material title, da'wah message classification, tagline; (b) audience, consisting of congregation in studio, at home, ratings level, and program share; (c) workers, related to the selection of dai as a source, host and guest; (d) religious values represented with the substantive content of da'wah message. It shows commodification symptoms exist in four categories : communication content, audience, show cast (workers), and religious values. The negative effects of these externalities are more than positive ones.
\end{abstract}

Key words: Dakwahtainmennt, Commodification, Externalities Effects 


\section{Pendahuluan}

Televisi merupakan media massa yang memiliki pengaruh terhadap pemikiran dan perilaku masyarakat. Hasil survei Polling Center menunjukkan bahwa sekitar 77,7 persen masyarakat Indonesia mengaku menonton televisi secara rutin setiap harinya. ${ }^{1}$ Untuk itu tayangan televisi yang berkualitas sangat penting bagi masyarakat. Pada tahun 2017, hasil penilaian Komisi Penyiaran Indonesia menunjukkan bahwa tayangan wisata dan budaya, serta religi adalah tayangan dengan nilai indeks pada peringkat pertama dan kedua, sementara yang terakhir (nilai indeks kualitas program paling rendah) adalah sinetron dan infotainment. Namun dalam survei, justru rating tertinggi adalah program sinetron. Secara keseluruhan nilai indeks kualitas program televisi nasional masih rendah. ${ }^{2}$

Maraknya tayangan religi dalam dekade terakhir dapat menjadi angin segar untuk meningkatkan indeks kualitas program televisi. Jika dulu tayangan religi hanya ramai saat bulan Ramadan, kini pada bulan-bulan biasa juga banyak tayangan religi di televisi. Sebut saja seperti program: Damai Indonesiaku di TV One, Semesta Bertasbih dan Kata Ustaz Solmed di SCTV, Islam Itu Indah di Trans TV, Mamah \& Aa Beraksi di Indosiar, dan sebagainya. ${ }^{3}$ Sebagian besar dari tayangan program religi tersebut memasukkan unsur hiburan di dalamnya

\footnotetext{
1 Polling Center, Laporan Naratif Propinsi-propinsi Aceh, DKI Jakarta, Jawa Timur, Kalimantan Timur, Sulawesi Selatandan Nusa Tenggara Timur - Survei Dasar terhadap Pemahaman, Persepsi dan Praktik Pemilih Terkait dengan Aspek Pemilu di Enam Target Propinsi (Polling Center: November 2013), 97. https://antikorupsi.org/sites/default/files/doc/Politik \%20Uang/Laporan\%20Naratif Survei\%20dasar\%20ter hadap\%20KAP\%20pemilih\%20di\%20Enam\%20Propins i Total\%206\%20Provinces 2013.pdf

$2 \mathrm{KPI}$, "Hasil Survei KPI Kualitas Sinetron Makin Terpuruk," KPI.go.id. modified Februari 4, 2017. https://www.kpi.go.id/index.php/lihat-terkini/38dalam-negeri/33587-hasil-survey-kpi-kualitassinetron-makin-terpuruk

3 Aulia Adam, "Wajah Acara TV: Ramai-Ramai Menayangkan Konten Dakwah Islami," Tirto.id, 06 Juni 2018. https://tirto.id/wajah-acara-tv-ramai-ramaimenayangkan-konten-dakwah-islami-cLKs
}

dengan menyajikan pertunjukkan musik, mengundang artis, ada muatan lelucon, kuis, dan sebagainya. Konsep sajian dakwah televisi yang menggabungkan hiburan di dalamnya untuk menarik perhatian pemirsa disebut dengan dakwahtainment. ${ }^{4}$

Tayangan program religi di televisi tersebut dapat menjadi bagian dari siar atau dakwah Islam. Dakwah adalah seruan, ajakan, anjuran yang bersifat persuasif. ${ }^{5}$ Televisi adalah salah satu media dakwah yang dipandang oleh beberapa pakar memiliki efektivitas dan efisiensi yang tinggi untuk mencapai tujuan dakwah. ${ }^{6}$ Dalam konteks masyarakat Indonesia, menjadikan televisi sebagai media dakwah sangat relevan dengan keadaan masyarakat yang umumnya berada pada tahapan hearing and watching (mendengar dan melihat), dan mayoritas umat Islam. ${ }^{7}$ Sebagai medium siaran publik yang bersifat audiovisual, televisi dapat didengar dan dilihat bila ada siaran, daya rangsang yang tinggi, dan daya jangkau yang luas, meskipun secara biaya untuk produksi cukup mahal. ${ }^{8}$ Di situlah televisi dapat menjadi media yang efektif dan efisien dalam dakwah.

Namun televisi bukan sekadar medium siaran publik, tetapi telah menjadi industri. Televisi sebagai industri media tidak terlepas dari pengembangan kapital, di antaranya melalui iklan, jam tayang khusus, dan lain-

\footnotetext{
4 Aris Saefulloh, "Dakwahtainment: Komodifikasi Industri Media di Balik Ayat Tuhan," Komunika: Jurna Dakwah dan Komunikasi vol. 3, no. 2 (2009): 255-269; Dicky Sofjan (with Mega Hidayati), Religion and Television in Indonesia Ethics Surrounding Dakwahtainment (Geneva: Globethics.net, 2013), 4849.

5 M. Ali Aziz, Ilmu Dakwah Edisi Revisi (Jakarta: Prenadamedia Grup, 2016), 17-18.

${ }^{6}$ M. Ali Aziz, Ilmu Dakwah, 424; Samsul Munir Amin, Ilmu Dakwah, (Jakarta: Kreasindo Mediacita, 2009) 120.

${ }^{7}$ Ahmad Atabik, "Prospek Dakwah Melalui Televisi," AtTabsyir: Jurnal Komunikasi Penyiaran Islam vol. 1, no. 2 (September 2015): 191-209.

8 Morissan, Jurnalistik Televisi Mutakhir (Jakarta: Kencana, 2010), 4.
} 
lain. Melalui siaran televisi, budaya populer terbentuk dan memengaruhi masyarakat secara luas. Televisi adalah sumber daya yang terbuka bagi semua orang dalam masyarakat industri, dan sumber bagi pengetahuan populer tentang dunia. ${ }^{9}$ Televisi dengan karakteristiknya akan dapat memberikan dampak positif jika informasi yang disampaikan berisi pesan-pesan yang baik dan bermoral. Sebaliknya, akan menimbulkan bahaya besar ketika televisi menyiarkan program-program yang bobrok dan amoral, seperti unsur kekerasan, pembodohan, penyesatan, mistik, dan seks. ${ }^{10}$

Acara dakwah di televisi memang dapat menjawab kebutuhan seorang muslim akan wawasan keagamaan dan siraman rohani. Industri media televisi di Indonesia dengan jeli menangkap kebutuhan tersebut. Di sinilah kemudian televisi mengemas sedemikian rupa acara-acara bernuansa religi atau dakwah semenarik mungkin, yang memasukkan unsur hiburan di dalamnya dengan menyajikan pertunjukan musik, mengundang artis, ada muatan lelucon, kuis, dan sebagainya. Konsep sajian dakwah televisi yang menggabungkan hiburan di dalamnya untuk menarik perhatian pemirsa disebut dengan dakwahtainment. ${ }^{11}$ Yang menjadi masalah adalah terkadang aspek isi atau materi dakwah tidak ditekankan, tetapi bagaimana bisa menarik minat pasar, sehingga kalaupun acara dakwah, haruslah acara dakwah yang menghibur. Sebab publik, khususnya yang tinggal di perkotaan, juga membutuhkan hiburan sebagai obat dari kepenatan rutinitas kehidupan modern yang kompleks. Hal-hal tersebut mengindikasikan bahwa industri media

${ }^{9}$ Chris Barker, Cultural Studies Teori dan Praktik, Terj. Nurhadi (Yogyakarta: Kreasi Wacana, 2006), 275.

10 Kierstin Bible, "Book Review: Amusing Ourselves to Death - Public Discourse, 1-25.

${ }^{11}$ Saefulloh, "Dakwahtainment: Komodifikasi Industri Media," 55-269; Dicky Sofjan, Religion and Television, 48-49.

12 M. Ali Aziz, Ilmu Dakwah., 19-20. penyiaran telah menjadikan kegiatankegiatan dakwah untuk meningkatkan rating dan meraih untung.

Dalam konteks yang demikian, maka dakwah dengan segala unsur di dalamnya telah menjadi komoditas dan bagian dari produk budaya populer. Padahal dakwah pada hakikatnya mengajak dan menawarkan gagasan ajaran Islam kepada mitra dakwah sebagai pasar. Harapannya pasar dapat menerima ajaran Islam dengan kesadaran, ${ }^{12}$ artinya dilandasi ilmu pengetahuan yang bisa dipertanggungjawabkan dan terinternalisasi dalam diri, bukan ikutikutan. Maka dakwah yang dikemas dalam media televisi akan cenderung menjadi industri, artinya dakwah dengan segala aspeknya dijadikan sebagai komoditi dan bagian dari produk budaya populer, ${ }^{13}$ yang kemudian dijual ke pasar. Fenomena tersebut dapat diindikasikan sebagai kegiatan komodifikasi. Bila komoditas adalah hasil kerja manusia, baik berupa barang atau jasa, yang sengaja diproduksi untuk dipertukarkan melalui mekanisme pasar, maka komodifikasi adalah menjadikan sesuatu yang bukan komoditas kemudian seolah-olah menjadi komoditas atau diperlakukan seperti halnya komoditas yang bisa diperjualbelikan demi laba. ${ }^{14}$

Sebagai suatu kegiatan komodifikasi dalam siaran publik, tayangan dakwahtainment di TV tentu memiliki efek eksternalitas. Efek eksternalitas pada kegiatan komersil dan siaran publik merupakan efek yang terjadi pada pasar yang tidak dipertimbangkan. Efek-efek tersebut dieksternalkan oleh produser dan konsumen itu sendiri. ${ }^{15}$ Sebagai dampak keluar dari adanya sebuah

13 Saefulloh, "Dakwahtainment: Komodifikasi," 255269.

${ }^{14}$ Bagong Suyanto, Sosiologi Ekonomi: Kapitalisme dan Konsumsi di Era Masyarakat Post-Modernisme (Jakarta: Kencana, 2013), 175-178.

15 Edward S. Herman, "The Externalities Effects of Commercial and Public Broadcasting," in P. Golding and G. Murdock. The Political Economy of the Media. (Edward Elgar Publishing, 1997), 379. 
siaran publik, efek eksternalitas bisa bersifat positif atau negatif. Dalam konteks industri siaran komersil ada yang menyebut bahwa tidak ada efek eksternalitas yang bersifat positif, semuanya bersifat negatif, sebab menekankan pada prinsip keuntungan bagi perusahaan. ${ }^{16}$

Salah satu acara dakwahtainment yang populer di masyarakat adalah Islam Itu Indah yang ditayangkan oleh Trans TV. Acara tersebut pertama kali tayang tahun 2010, dan terus bertahan hingga kini. Dalam studi analisis brand awareness acara dakwahtainment tahun 2013, ${ }^{17}$ diketahui bahwa acara Islam Itu Indah menempati posisi top of mind para responden, artinya acara tersebut adalah yang paling diingat di benak responden. Hasil rating pada periode Oktober 2017, untuk acara Is/am Itu Indah adalah 1,2 dan tingkat share 15,9, menjadi yang tertinggi untuk program sejenis. ${ }^{18}$

Sebagai acara dakwahtainment dengan rating tinggi, dan tingkat pengenalan merek (brand awareness) yang kuat, program Islam Itu Indah tidak terlepas dari komodifikasi dalam siaran publik. Sebab ada proses untuk mencapai rating, memperkuat merek, dan mempertahankan acara selama sepuluh tahun. Hal itulah yang mendasari studi ini menggali lebih dalam komodifikasi dan efek eksternalitas dalam program dakwahtainment Islam Itu Indah. Fokus masalah dalam studi ini dirumuskan sebagai berikut: (1) bagaimana bentuk-bentuk komodifikasi dalam program Islam Itu Indah dengan pendekatan semiotik? (2) bagaimana efek eksternalitas dari komodifikasi program Islam Itu Indah? Efek eksternalitas tersebut terkait keadaan pasar, khususnya umat Islam di Indonesia.

\footnotetext{
16 Ibid., 374.

17 M. Nurrokhim, "Analisis Brand Awareness dan Brand Association Acara Dakwah di Televisi," Jurnal Kajian dan Pengembangan Manajemen Dakwah vol. 03, no. 02 (Des. 2013): 143-158.

18 Novi Andayani Praptiningsih dan Ami Kusuma Handayani, "Problematika Produksi Program Dakwah
}

Diharapkan hasil studi ini bermanfaat sebagai bahan untuk memberikan masukan kepada para pelaku dakwah di Indonesia terkait penyikapannya terhadap acara dakwah di televisi, juga kepada umat Islam Indonesia selaku pasar.

Studi ini menggunakan metodologi analisis teks dengan pendekatan semiotik. Analisis teks dipilih karena subjek dalam studi ini adalah media televisi yaitu program Islam Itu Indah yang menampilkan berbagai macam teks dalam komunikasi media massa. Semiotika sebagai disiplin yang mempelajari hakikat keberadaan suatu tanda, ${ }^{19}$ dipilih karena studi ini menggali sesuatu di balik teks yaitu tanda-tanda yang diinterpretasikan sebagai bentuk-bentuk komodifikasi dan efek eksternalitasnya. Tanda yang menjadi objek kajian semiotik adalah kata (bahasa), ekspresi wajah, isyarat tubuh, film, sign, dan karya sastra yang mencakup musik ataupun hasil kebudayaan dari manusia itu sendiri. ${ }^{20}$ Data-data terkait acara Islam Itu Indah di Trans TV dikumpulkan dengan teknik dokumentasi tayangan program Islam Itu Indah di kanal media sosial YouTube dan Instagram, serta menyaksikan secara langsung tayangan program di Trans TV. Data-data penunjang dikumpulkan dari hasil studi terkait yang dipublikasikan dalam jurnal ilmiah maupun laporan penelitian. Adapun sampel yang diambil dari keseluruhan tayangan adalah tiga bulan terakhir saat studi ini dilakukan yaitu periode Desember 2019 sampai dengan Februari 2020, dengan total 91 episode. Jumlah tersebut dipandang relevan dan cukup mewakili sebagai bahan analisis komodifikasi secara semiotik.

Religi Televisi Islam Itu Indah," Prosiding Seminar Nasional dan Kolokium vol. 1, no.1 (2017):113-128.

${ }^{19}$ Alex Sobur, Analisis Teks Media Suatu Pengantar untuk Analisis Wacana, Analisis Semiotik, dan Analisis Framing (Bandung: Remaja Rosdakarya, 2009), 87.

20 Ibid., 5. 
Tahapan analisisnya, pertama, mengidentifikasi bentuk-bentuk komodifikasi yang terjadi dalam program Islam Itu Indah dengan pendekatan semiotik. Langkahnya adalah (1) mengidentifikasi tanda-tanda komodifikasi dalam program meliputi komodifikasi konten, khalayak, tenaga kerja, dan nilai-nilai secara semiotik; (2) menginterpretasi makna dalam struktur tanda tersebut; (3) mengonstruksi makna tanda tersebut dengan gejala/indikator komodifikasi pada tiap dimensi; (4) menyimpulkan bentuk-bentuk komodifikasi dalam program. Kedua, menganalisis efek eksternalitas yang terjadi karena komodifkasi dalam program tersebut. Langkahnya adalah (1) mengidentifikasi akibat-akibat logis yang terjadi pada publik dalam aspek pemikiran, perasaan, dan perilaku; (2) menganalisis data-data pemberitaan dan hasil studi terkait pengaruh tayangan program Islam Itu Indah; (3) menyimpulkan efek eksternalitas yang terjadi.

Studi mengenai komodifikasi acara dakwahtainment maupun yang secara spesifik membahas program Islam Itu Indah di televisi telah cukup banyak dilakukan, di antaranya, pertama, tesis berjudul Komodifikasi Dakwah Dalam Siaran Televisi (Analisis Wacana Kritis Program Religi "Islam Itu Indah" di Media Trans TV) oleh Ridwan Rustandi. ${ }^{21}$ Penelitian tersebut bertujuan untuk mengetahui upaya komodifikasi dakwah yang dilakukan dalam siaran televisi, dalam hal ini adalah program Islam Itu Indah. Fokus masalahnya adalah bagaimana identitas dai dan konstruksi pesan dakwah (maddah) dikemas dalam program dakwah Islam Itu Indah. Pendekatannya adalah

21 Ridwan Rustandi, "Komodifikasi Dakwah Dalam Siaran Televisi: Analisis Wacana Kritis Program Religi "Islam itu indah" di Media Trans TV" (Masters thesis, UIN Sunan Gunung Djati Bandung, 2017).

22 Ridwan Rustandi, "Analisis Wacana Kritis Komodifikasi Dai dalam Program Televisi," Communicatus: Jurnal Ilmu Komunikasi vol. 2, no. 2 (2018): 197-222. analisis wacana kritis. Hasil penelitian menunjukkan bahwa komodifikasi dakwah dilakukan pada sisi dai dan maddah. Pada sisi dai, komodifikasi terjadi dalam pemilihan dai yang ditentukan dengan mempertimbangkan kriteria seperti unifikasi (karakter pembeda), daya jual (popularitas dan publisitas), keterampilan dan kecakapan berbicara, serta kualifikasi keilmuan. Pada sisi pesan, komodifikasi ditemukan dalam proses penentuan tema dan pola pengemasan acara. Dalam konteks analisis wacana kritis ditemukan bahwa tema pokok kajian dominan berkenaan dengan akhlak dan muamalah. Tesis tersebut sebagiannya juga dipublikasikan dalam artikel jurnal berjudul "Analisis Wacana Kritis Komodifikasi Daí Dalam Program Televisi."22

Kedua, skripsi berjudul "Komodifikasi Agama Dibalik Ceramah Islam Itu Indah Ustad Maulana." Tujuan penelitiannya adalah untuk mengetahui bentuk komodifikasi dalam tayangan ceramah "Islam Itu Indah" Trans TV. Metode yang dipakai dalam analisis ini yaitu teori McDonaldisasi yang ditulis oleh George Ritzer. Kesimpulan yang didapatkan adalah bahwa dalam komodifikasi agama melalui ceramah "Islam Itu Indah," agama hanya dilihat sebagai komoditas dalam sistem pasar. Definisi mutu ceramah Islam tidak lagi dirumuskan dari ukuran tema yang diangkat atau seberapa dalam penceramah mendalami ilmu agama Islam melainkan oleh parameter industrial. ${ }^{23}$

Ketiga, studi berjudul "Komodifikasi Dakwah Dalam Religiotainment di Stasiun Televisi Indonesia." Studi tersebut berangkat dari maraknya program dakwah di televisi, di mana agama telah menjadi komoditas.

23 Nuri Amila, "Komodifikasi Agama Dibalik Ceramah Islam Itu Indah Ustad Maulana." blogspot.

http://nouriesblog.blogspot.com/search/label/K omodifikasi 
Pendekatan yang digunakan adalah posisi media massa dalam sistem kapitalis, serta komodifikasi dan akumulasi kapital. Media sebagai industri yang berorientasi pasar dan dihadapkan pada persaingan, mengemas program dakwahnya sedemikian rupa untuk memenuhi selera pasar. Komodifikasi dakwah inilah yang saat ini mewarnai potret dakwah Indonesia di televisi. ${ }^{24}$

Perbedaan studi ini dengan studi-studi di atas, pertama, pendekatannya berbeda, studi di atas ada yang menggunakan analisis wacana kritis, teori mcdonaldisasi, dan media massa dalam sistem kapital. Sementara studi ini menggunakan analisis semiotik, komodifikasi dan efek eksternalitas. Kedua, sekalipun sama-sama menjadikan program Islam Itu Indah sebagai subjek, namun fokus kajian komodifikasinya berbeda. Bila studi pertama (tesis) berfokus pada dai dan konstruksi pesan dakwah, studi kedua (skripsi) berfokus pada komodifikasi agama (nilai-nilai) yang diidentifikasi dari ceramah narasumber program, maka studi ini mencakup empat aspek komodifikasi, yaitu konten komunikasi, khalayak, tenaga kerja, dan nilai-nilai (agama). Ketiga, secara khusus studi ini menghubungkan antara komodifikasi yang terjadi dengan efek eksternalitas yang dihasilkan. Dengan demikian posisi studi ini jelas berbeda dengan studi-studi sebelumnya, dan melengkapi khazanah studi komodifikasi acara dakwahtainment di televisi.

\section{Komodifikasi dan Efek Eksternalitas Dalam Program Dakwahtainment}

\footnotetext{
24 Fitri Murfianti, "Komodifikasi Dakwah dalam Religiotainment di Stasiun Televisi Indonesia," Pendhapa: Jurnal ilmiah Pengkajian \& Penciptaan Seni Rupa dan Desain vol. 3, no. 1 (2012). 25 Vincent Mosco, Political Economy of Communication, (London: Sage Publication, 1996), 127-129.

26 Idi Subandy Ibrahim and Bachruddin Ali Akhmad Komunikasi dan Komodifikasi: Mengkaji Media dan
}

Konsep mengenai komodifikasi ditulis oleh Mosco dalam bukunya berjudul Political Economy of Communication yang mengatakan bahwa komodifikasi merupakan cara kapitalisme membawa tujuan-tujuan kapital, salah satunya adanya perubahan nilai guna menjadi nilai tukar dengan berbagai macam bentuk. ${ }^{25}$ Ibrahim dan Akhmad menyatakan bahwa komodifikasi adalah proses transformasi barang dan jasa yang semula dinilai karena nilai gunanya, menjadi komoditas yang bernilai karena ia bisa mendatangkan keuntungan di pasar setelah dikemas sedemikian rupa. 26 Sederhananya komodifikasi adalah proses perubahan nilai guna menjadi nilai tukar. Paksaan dan tekanan pada perolehan hasil balik modal yang datang dari pasar bebas, akan memaksa perusahaan untuk fokus pada peningkatan intensitas dan perluasan ukuran audiens dan meningkatkan kualitas pasar yang nantinya hal ini menentukan rating dan jumlah iklan yang diperoleh. ${ }^{27}$

Mosco menjelaskan bahwa terdapat tiga jenis komodifikasi yang penting bagi komunikasi, yaitu, komodifikasi konten, komodifikasi khalayak, dan komodifikasi tenaga kerja. Komodifikasi konten di antaranya dengan cara membentuk konten bahkan melakukan manipulasi konten agar menjadi lebih menarik dan laku untuk dijual. Isi atau pesan yang dikomodifikasi diubah oleh pelaku media melalui teknologi ke dalam interpretasi yang penuh makna, sehingga menjadi marketable. Media memodifikasi konten dengan beragam nilai citra yang dipandang sesuai selera pasar. ${ }^{28}$ Komodifikasi khalayak atau audiens,

Budaya dalam Dinamika Globalisasi (Jakarta: Yayasan Obor, 2014), 17

27 Edward S. Herman, "The Externalities effects of Commercial and Public Broadcasting," 381.

28 Khoiruddin Muchtar and Faula Rahma Ghalia. "Respon Mahasiswa Terhadap Tayangan Dakwah Islamiyah Khazanah (Trans7) dan Damai Indonesiaku (TV One)." Interdisciplinary Journal of Communication vol. 3 , no. 2 (2018): 147-174. 
khalayak dikomodifikasi dalam upaya untuk memahami praktik umum dengan cara para pengiklan membayar untuk ukuran dan kualitas khalayak yang dapat diraih saluran media tertentu. ${ }^{29}$ Audiens dijual kepada perusahaan produksi yang melakukan pengiklanan dalam ukuran jumlah, sehingga para industri televisi swasta memperoleh keuntungan dengan menjual angka audiens tersebut dan memperoleh air time. Bentuk komodifikasi khalayak yang paling sering dilakukan adalah melalui rating dan share. Tinggi rendahnya rating dalam sebuah mata acara dapat menentukan sedikit atau banyaknya pengiklan di media tersebut. ${ }^{30}$ Komodifikasi tenaga kerja, yang berfungsi sebagai penggerak produksi konten televisi. Pekerja dioptimalisasi bahkan dieksploitasi tenaga, pikiran, dan perasaannya untuk memperoleh keuntungan setinggi-tingginya dari hasil produksi konten dengan biaya seminim-minimnya. ${ }^{31}$ Komodifikasi tenaga kerja meliputi para pekerja produksi, distribusi acara, dan para pengisi acara.

Jenis komodifikasi lain ditambahkan Ibrahim dan Akhmad, yaitu komodifikasi nilai. ${ }^{32}$ Komodifikasi nilai yang dimaksud menjelma dalam bentuk proses komodifikasi yang menguat dalam dunia pendidikan dan agama. Dalam bukunya Consuming Religion, Miller menjelaskan bahwa bahaya nyata budaya konsumen (konsumerisme) adalah dia dapat menjangkiti segenap kapasitas masyarakat untuk menerima apa yang bernilai. Konsumerisme secara halus menjerat masyarakat dalam sebuah jaringan tafsir konsumen dan keterlibatan dengan semua sistem nilai, termasuk yang dimiliki seseorang. Daya tarik agama sebagai objek budaya berakar dalam imaji diri yang lazim terdapat dalam masyarakat konsumen. ${ }^{33}$ Kittiarsa berpendapat bahwa komodifikasi

${ }^{29}$ Ibrahim dan Akhmad, Komunikasi dan Komodifikasi, 20.

30 Rustandi, "Analisis Wacana," 197-222.

31 Mosco, The Political Economy., 127-129.

32 Ibrahim dan Akhmad, Komunikasi, 22. agama berarti mengubah agama menjadi nilai-nilai yang dapat dijual, membawanya ke dalam berbagai skala dan cara transaksi pasar. Proses komodifikasi agama akan berjalan lancar ketika agama telah terprivatisasi, artinya setiap individu memiliki otoritas untuk menentukan pola keberagamaannya, sehingga agama secara teoretis terdefinisikan ulang sebagai komoditas. ${ }^{34}$ Dalam siaran agama Islam yang bercorak dakwahtainment, nilai-nilai agama Islam dikomodifikasi sedemikian rupa untuk memenuhi kebutuhan pasar. Nilai-nilai agama hanya sekadar dijadikan produk yang ditawarkan dan dikonsumsi sesuai selera pasar. Di sinilah bahayanya komodifikasi agama, yang bisa menggeser nilai-nilai agama dalam budaya populer dan akhirnya mereduksi makna agama itu sendiri. Studi ini mengidentifikasi keempat dimensi komodifikasi tersebut.

Komodifikasi dalam kegiatan penyiaran televisi akan menghasilkan efek eksternalitas. Efek eksternalitas pada kegiatan komersil dan siaran publik merupakan efek yang terjadi pada pasar yang tidak dipertimbangkan. Efek-efek tersebut dieksternalkan oleh produser dan konsumen itu sendiri. ${ }^{35}$ Efek eksternalitas memiliki dua muatan nilai, nilai negatif dan nilai positif, artinya ada efek yang memberikan pengaruh positif terhadap pasar dan ada yang memberikan efek negatif seperti kekerasan, asusila, degradasi nilai politik, dan agama. Efek eksternalitas bermuatan positif muncul biasanya pada siaran publik karena tidak memiliki kepentingan profit dan tidak dibiayai oleh iklan serta siaran publik ini menjadi alat untuk pelatihan, pendidikan, dan layanan lainnya yang mementingkan kepentingan

\footnotetext{
33 Ibid., 22-23.

34 Pattana Kittiarsa, ed, Religious Commodifications in Asia: Marketing Gods. (London: Routledge, 2008), 112.

35 Herman, "The Externalities Effects," 379.
} 
publik. ${ }^{36}$ Namun efek eksternalitas positif tidak memiliki tempat dalam sistem komersil (swasta). Efek eksternalitas seringkali bermuatan negatif dalam sistem komersil dikarenakan sistem ini menggunakan prinsip untung bagi perusahaan, bukan untung bagi publik, kecuali perusahaan media adakalanya memilki program yang memiliki layanan publik dengan keuntungan relasi publik. $^{37}$

Kadang efek negatif tersebut sudah diketahui oleh perusahaan televisi namun karena tindakan mencegah atau mengatasinya memerlukan biaya tersendiri yang tidak kecil, maka efek-efek tersebut tidak diindahkan, karena mencegahnya sama dengan meningkatkan biaya produksi yang merugikan. ${ }^{38}$ Permasalahan efek eksternalitas negatif dalam tayangan komersil telah lama dibahas dan banyak pihak yang mempertanyakan maupun komplain langsung pada produser dan pihak perusahaan media. Namun pada perkembangannya efek-efek negatif tersebut terus dieksternalkan dan dijawab dengan argumentasi yang sama yakni pihak perusahaan hanya memenuhi kebutuhan pasar. Hal ini juga menjadi jawaban juru bicara jaringan penyiaran ketika menanggapi mengenai komplain massa terhadap dampak negatif dari tayangan kekerasan di televisi Amerika. ${ }^{39}$ Padahal dalam logika industri media, pasar dapat diciptakan dan dibentuk sedemikian rupa agar menjadi sasaran empuk para pegiat komersil, sehingga tidak mungkin pihak media hanya menuruti pasar saja. Oleh karenanya dalam penelitian efek eksternalitas berjalan dengan logika sebab akibat. ${ }^{40}$

\footnotetext{
36 Ibid., 382.

37 Ibid., 380.

38 Ibid., 380.

39 Frank Mankiewicz and Joel Swerdlow, Remote Control: Television and the Manipulation of American Life (New York: Ballantine Books, 1979), 45.

40 Herman, "The Externalities Effects," 383.
}

Dakwahtainment sebagai program siaran televisi komersil mencakup unsur dakwah dan hiburan. Dakwah pada hakikatnya merupakan kendaraan untuk menyampaikan pesan agama, mengajak manusia pada sistem moral yang dilandasi kebaikan (makruf) dan mencegah dari keburukan (mungkar). ${ }^{41}$ Dimensi dakwah meliputi: dai (pelaku/subjek dakwah); mad'uw (mitra dakwah); maddah (materi dakwah); wasilah (media dakwah); thariqah (metode dakwah), dan atsar (efek dakwah). ${ }^{42}$ Sementara entertainment/hiburan adalah sesuatu atau kegiatan yang dapat menyenangkan, menyejukkan hati yang susah, atau melipur lara. ${ }^{43}$ Hiburan dapat berupa komedi, film, musik, olahraga, rekreasi, dan sebagainya yang itu menjadi kebutuhan alamiah manusia. Televisi sebagai komunikasi massa memang salah satu fungsinya adalah memberikan hiburan, selain fungsi pengawasan, penafsiran, keterikatan, dan penyebaran nilai. ${ }^{44}$ Dalam kegiatan dakwah, hiburan bisa terkait penggunaan metode dan teknik dakwah yang menyenangkan, muatan atau selipan yang menghibur dalam materi dakwah, penggunaan media, keberadaan subjek, dan lain-lain. Sehingga jika dirangkum dalam kegiatan dakwahtainment setidaknya meliputi dimensi subjek, materi, metode, media, dan mitra dakwahtainment. Kelima hal itulah yang akan dideskripsikan lebih lanjut sebagai bahan analisis komodifikasi dan efek eksternalitasnya dalam program Islam Itu Indah.

Sejalan dengan pendapat Herman di atas, maka program Islam Itu Indah sebagai bagian dari dakwahtainment dalam siaran

\footnotetext{
${ }^{41}$ A. Ilyas Ismail and Prio Hotman, Filsafat Dakwah: Rekayasa Membangun Agama dan Peradaban Islam (Jakarta: Kencana, 2011), 38.

42 Aziz, Ilmu Dakwah, 75, 92, 94, 120.

43 KBBI "hiburan" https://kbbi.kemdikbud.go.id/entri/hiburan

${ }^{44}$ Elvinaro Ardianto, Lukiati Komala E, and Siti Karlinah, Komunikasi Massa Suatu Pengantar, Edisi Revisi (Bandung: Simbiosa Rekatama Media, 2007).
} 
komersil di Indonesia, dapat dihipotesiskan memiliki efek eksternalitas yang bernilai negatif bagi publik, khususnya umat Islam. Namun apa yang dikemukakan oleh Herman bersifat general dan lebih banyak mengambil contoh dalam konteks penyiaran televisi di Amerika. Untuk itu studi ini akan mendalami lebih lanjut efek eksternalitas program dakwahtainment bagi umat Islam di Indonesia, dan menguji hipotesis tersebut.

\section{Semiotika Sebagai Pendekatan Analisis Teks Media}

Bentuk komodifikasi tidak selalu nampak jelas (eksplisit) dalam komunikasi di media. Malah sering tersembunyi di balik bahasa, simbol, ekspresi, dan ragam tanda lainnya. Untuk itu pendekatan semiotik digunakan dalam studi ini. Semiotik mempelajari hakikat tentang keberadaan suatu tanda. Menurut Saussure, persepsi dan pandangan manusia terhadap realitas dikonstruksikan oleh kata-kata dan tanda-tanda lain dalam suatu konteks sosial. ${ }^{45}$ Teks media yang tersusun atas seperangkat tanda tersebut tidak pernah membawa makna tunggal, yang memiliki ideologi dominan yang terbentuk melalui tanda tersebut. ${ }^{46}$

Saussure mengungkapkan bahwa dalam konteks komunikasi manusia, tanda dibedakan antara apa yang disebut signifier (penanda) dan signified (petanda). Signifier adalah bunyi atau coretan yang bermakna (aspek material). Signified adalah pikiran atau konsep, aspek mental dari bahasa. Hubungan antara keberadaan fisik tanda dan konsep mental dinamakan signification. Sehingga signification adalah upaya dalam memberi makna terhadap dunia. ${ }^{47}$ Hubungan antara signifier dan signified ini dibagi tiga, yaitu: (1) Ikon, adalah tanda yang

45 Sobur, Analisis Teks, 87-88.

46 lbid., 95.

47 John Fiske, Introduction to Communication Studies. Second Edition (London: Routledge, 1990), 44. memunculkan kembali benda atau realitas yang ditandainya, misalnya foto atau peta; (2) Indeks adalah tanda yang kehadirannya menunjukkan adanya hubungan dengan yang ditandai, misalnya asap adalah indeks dari api; (3) Simbol adalah sebuah tanda di mana hubungan antara signifier dan signified semata-mata adalah masalah konvensi, kesepakatan atau peraturan. ${ }^{48}$

Roland Barthes telah membuat model analisis makna dari tanda-tanda. Fokus perhatian Barthes lebih tertuju kepada gagasan tentang signifikasi dua tahap (two order of signification). Signifikasi tahap pertama (first order) merupakan hubungan antara signifier dan signified di dalam sebuah tanda terhadap realitas eksternal yang disebut sebagai denotasi, yaitu makna paling nyata dari tanda (reality). Signifikasi tahap kedua (second order) disebut konotasi, yaitu interaksi yang terjadi ketika tanda bertemu dengan perasaan atau emosi dari pembaca serta nilai-nilai dari kebudayaannya. Sehingga konotasi mempunyai makna yang subjektif. ${ }^{49}$

Dalam studi ini komodifikasi akan diidentifikasi dari analisis makna tandatanda yang tersaji dalam program Islam Itu Indah melalui signifikasi dua tahap, yaitu makna denotasi (reality), dan makna konotasi (sosio cultural and myth). Adapun analisis efek eksternalitas didasarkan logika sebab akibat dari komodifikasi acara dakwah, ditunjang data-data terkait. Logika sebab akibat yang dimaksudkan adalah sejalan dengan aspek komodifikasi yang terjadi dalam siaran komersil. Ketika terjadi komodifikasi maka akan menghasilkan efek eksternalitas yang cenderung bernilai negatif. Namun dalam studi ini tidak mengingkari efek yang bermuatan positif,

${ }^{48}$ Aart van Zoest, "Interpretasi dan Semiotika," dalam Sudjiman P. dan Aart van Zoest (ed.), Serba-Serbi Semiotika (Jakarta: Gramedia Pustaka Utama, 1996), 23

${ }^{49}$ Fiske, Introduction to Communication., 88. 
yang akan digali lebih lanjut melalui datadata terkait.
Secara keseluruhan kerangka berpikir studi ini adalah sebagai berikut:
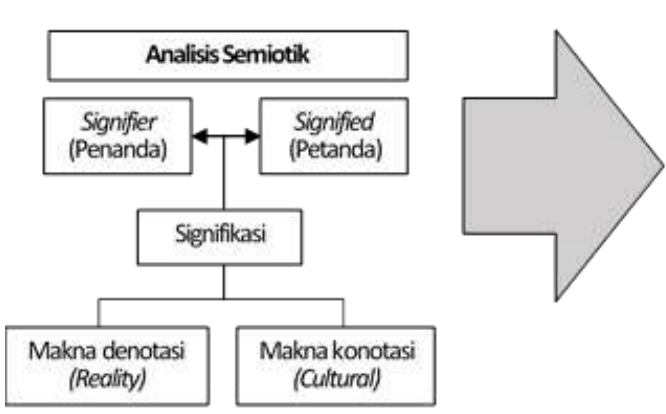

Komodifikasi Program Dakwahtainment Islam Itu Indah

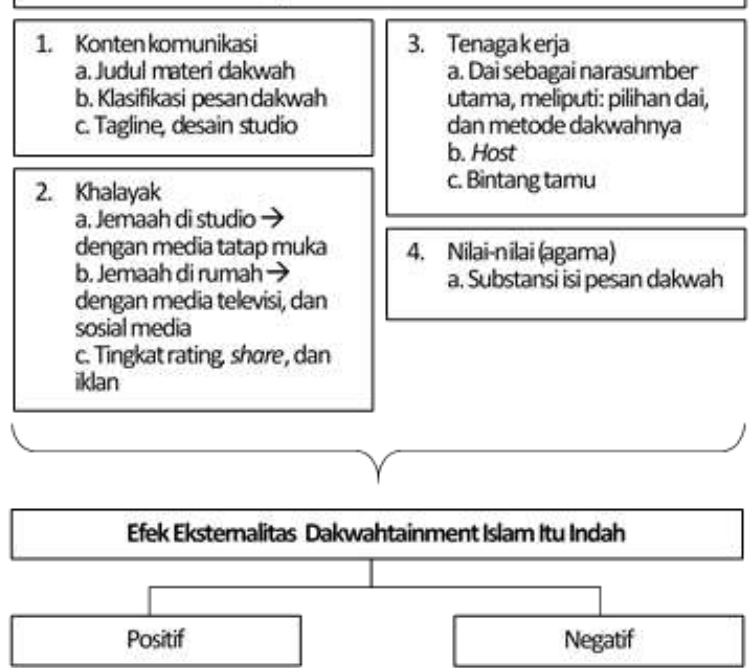

Gambar 1 - Sketsa Kerangka Berpikir Studi

\section{Islam Itu Indah sebagai Program Dakwahtainment}

Trans TV sebagai penyelenggara menjelaskan bahwa program Islam Itu Indah adalah program penyegaran rohani dan kalbu bagi keluarga dengan tausiah dan kajian agama Islam penuh inspirasi yang dibawakan Ustaz Maulana, Ustaz Syam, dan ustaz/ustazah pendukung lainnya. Program Islam Itu Indah juga menghadirkan bintang tamu dari kalangan selebritas, dan terdapat segmen tanya jawab seputar masalah keagamaan. Program tersebut tayang setiap hari pukul 05.00 sampai dengan 06.30 WIB. Selain itu juga di kanal YouTube Islam Itu Indah, website transtv.co.id secara daring atau streaming.$^{50}$ Visi dari program Islam Itu Indah adalah menjadi tontonan yang selalu dinanti oleh pemirsa, menghibur namun tetap mendidik tanpa menggurui, dan memberikan ilmu agama yang berguna

50 TransTV, "Islam Itu Indah," transtv.co.id, diakses Januari 2020, www.transtv.co.id/program/28/islamitu-indah

${ }^{51}$ Puspita Septi Mahardani, "Strategi Kreatif Program "Islam Itu Indah" di TRANS TV dalam Mempertahankan untuk mengatasi masalah kehidupan seharihari. ${ }^{51}$

Bermula dari rencana Trans TV untuk membuat program tayangan ceramah Islami dengan konsep yang ringan dan interaktif, menemukan rekaman Ustaz Maulana sedang bertausiah dengan pembawaan yang menarik, segar, dan menghibur. Trans TV kemudian mengundangnya ke Jakarta untuk melakukan syuting perdana. Akhirnya pada tanggal 12 Desember 2010, program Islam Itu Indah tayang untuk pertama kalinya. ${ }^{52}$ Gaya ceramah Ustaz Maulana yang sangat khas dengan aksen sapaannya, "Jamaah... Oh Jamaah... Alhamdulillah" menjadi ciri program ini. Pada tahun ketiga, tim kreatif program melakukan penyegaran dengan mendatangkan pembawa acara (host) program, dipilihlah Akhmad Fadil. Tahun keempat, Ustazah Oki Setiana Dewi masuk menjadi narasumber tetap dengan ciri cerita

Penonton Tahun 2016" (Undergraduated thesis, Universitas Muhammadiyah Yogyakarta, 2016), 67.

52 Ibid., 63-64. 
sejarah dan kisah insipratif. Tahun kelima Ustaz Syamsuddin Nur (Syam Elmarusyi) masuk menjadi narasumber dengan ciri khas bacaan Quran-nya yang indah. ${ }^{53}$ Lokasi syuting berpindah ke studio dengan format acara siaran langsung (live) dan tunda (taping), namun tetap sekali waktu juga bisa mengadakan syuting di luar.

Perkembangan terbaru saat studi ini dilakukan (akhir tahun 2019 dan awal 2020), tim kreatif terus melakukan penyegaran. Host progam ditambah, tidak hanya ada narasumber tetap tetapi juga ada narasumber pendamping yang bervariasi, baik itu ustaz maupun ustazah, yang dalam tiap kali tayangan terdapat dua sampai tiga ustaz/ustazah untuk mendampingi Ustaz Maulana dan Ustaz Syam. Desain studio juga diperbarui secara warna, setting tempat duduk, dan ornamen, namun tetap mempertahankan simbol-simbol religius. Sebagai acara dakwahtainment, Islam Itu Indah mengandung unsur-unsur dakwah dan hiburan (dakwahtainment), sebagai tandatanda yang memiliki signifikasi secara semiotik.

Berdasarkan pengumpulan data tayangan Islam Itu Indah periode Desember 2019 sampai Februari 2020, dimensi dakwahtainment dalam program dapat dideskripsikan sebagai berikut pertama, subjek dakwahtainment. Subjek dalam program dapat diklasifikasikan: (1) ustaz/narasumber tetap, yaitu Ustaz Maulana, dan Ustaz Syam; (2) Ustaz/narasumber pendamping, seperti: Ustaz Riza Muhammad, Habib Usman bin Yahya (suami artis Kartika Putri), Ustaz Koko
Liem yang terkenal sebagai ustaz ilusionis, Ustaz Taufiqurrahman terkenal sebagai ustaz pantun, Ustazah Oki Setiana Dewi (pemain film), Ustazah Lulung, dan lain-lain. Setiap ustaz yang tampil selalu memliki ciri khas/karakteristik yang unik; (3) host atau pembawa acara dari kalangan selebritas, yaitu Akhmad Fadli, Sonny Septian, Miqdad Addausy, Natasha Rizky, dan Chacha Frederica. Dalam setiap episode hanya ada satu host, sehingga kelima orang tersebut selalu bergantian dalam tiap episodenya. Kedua, mitra atau objek dakwahtainment terdiri dari pemirsa studio dan di rumah. Pemirsa di studio selalu menghadirkan kelompok ibu-ibu pengajian atau majelis taklim, kurang lebih dua sampai tiga kelompok. Sangat jarang pemirsa di studio dari kelompok pengajian bapak-bapak. Pemirsa di rumah adalah pemirsa Trans TV secara umum, dengan sasaran utama wanita dewasa, matang, dan usia lanjut.

Ketiga, materi dakwahtainment, yaitu materi dakwah yang dikemas/disajikan secara menghibur. Dalam setiap episode selalu menyajikan tema materi yang berbeda-beda. Namun jika diklasifikasi berdasarkan kedekatan konten tema, maka materi yang disajikan lebih banyak mengupas persoalan yang dekat dengan kehidupan sehari-hari, seperti soal keluarga, masalah jodoh, dan rezeki, pendidikan anak, pergaulan sosial, dan ibadah ritual. Istilah yang digunakan untuk judul tema materi juga dibuat menarik. Berdasarkan kedekatan konten tema, judul-judul materinya diklasifikasi menjadi delapan tema besar, yaitu sebagai berikut:

Tabel 1 - Klasifikasi Tema Materi Dakwahtainment Islam Itu Indah Periode Desember 2019 - Februari 2020

\begin{tabular}{lll}
\hline No & Klasifikasi Tema & \multicolumn{1}{c}{ Judul Materi } \\
\hline 1 & Keluarga dan & Ayah Ada, Ayah Tiada; Cara Ikhlas Menerima Kekurangan Pasangan; \\
& Rumah Tangga & Perempuan Pahlawan Devisa Keluarga; Doa Orang Tua Bagaikan Doa Nabi \\
& & kepada Umatnya; Bahagiain Istri Rezeki Tidak Berseri; Nikah Lama Makin
\end{tabular}

53 Mahardani, "Strategi Kreatif Program 'Islam Itu Indah' di TRANS TV," 65-66. 


\begin{tabular}{|c|c|c|}
\hline No & Klasifikasi Tema & Judul Materi \\
\hline & & $\begin{array}{l}\text { Romantis; Rezeki Seret? Salah Siapa?; Mertuaku Bawel; Laki-Laki yang Tak Lagi } \\
\text { Kuasa Menafkahi; Rumah Tangga Panas; Hujan Yang Berkah Bagi Kesehatan } \\
\text { dan Keluarga; Suami Instan; Pejuang Dua Garis Biru; Antara Ketegasan dan } \\
\text { Kekerasan dalam Rumah Tangga; Lakukan Hal Ini, Masalah Keuangan Keluarga } \\
\text { Hilang!; Ayah Rumah Tangga; Anak Yang Meninggal sebelum Melihat Wajah } \\
\text { Kedua Orang Tuanya; Budi Orang Tua Pada Anak. }\end{array}$ \\
\hline 2 & $\begin{array}{l}\text { Jodoh dan } \\
\text { Pernikahan }\end{array}$ & $\begin{array}{l}\text { Pilih Menikah Cepat, Atau Menikah Tepat?; Keutamaan Menjodohkan Orang } \\
\text { lain; Mahar Jangan Mahal; Jodohku Sampai Disini; Mahkota Pengantin Baru; } \\
\text { Pernikahan Jin; Pengantin Baru, Harus Gimana?; Alasan Kenapa Harus Nikah? } \\
\text { yang Terakhir Bikin Pengen Langsung Nikah; Antara Mapan dan Mantan. }\end{array}$ \\
\hline 3 & $\begin{array}{l}\text { Pendidikan Anak } \\
\text { dan Remaja }\end{array}$ & $\begin{array}{l}\text { Suara Hati Anak Broken Home; Mendidik Anak Menjadi Pecinta Bukan Penista; } \\
\text { Ekspektasi Orang Tua Versus Realita Anak; Krisis Percaya Diri Kaum Milenial; } \\
\text { Pendidikan Seks untuk Anak dalam Islam; Rasa Takut Anak Yang Abadi; Bahaya } \\
\text { Waktu Maghrib Bagi Anak; Keajaiban Rezeki Pada Anak; Masa Depan Anak } \\
\text { makin Mahal; Tujuh Rahasia Anak Jadi Rajin Solatnya; Istighfarnya Anak Sholeh } \\
\text { dan Sholehah; Obat Anak tantrum; Anak dan Orang Tua Dekat Bisa Bikin Sehat; } \\
\text { Anak sebagai Aset Berharga Orang Tua. }\end{array}$ \\
\hline 4 & Masalah Wanita & $\begin{array}{l}\text { Wanita dan Haid; Perempuan Pembawa Rezeki; Emang Ada Mandi Khusus } \\
\text { Buat Perempuan?; Wanita Impian Berjuta Pria; Kecantikan Abadi Hingga } \\
\text { Surga; Rahasia Dibalik Kode Wanita Bagi Lelaki. }\end{array}$ \\
\hline 5 & Masalah Laki-Laki & $\begin{array}{l}\text { Laki-laki dan Masa Mudanya; Tempat Tinggal Jin pada Tubuh Lelaki; Letupan } \\
\text { Emosi Lelaki; Ketika Laki-laki Berbohong; Para Lelaki Penumpas Dajal. }\end{array}$ \\
\hline 6 & $\begin{array}{l}\text { Akhlak dan } \\
\text { Pergaulan Sosial }\end{array}$ & $\begin{array}{l}\text { Ikhlas membuat Banjir Rezeki; Mudahnya Kita Menghina; Lelah Yang Bernilai } \\
\text { Berjuta Pahala; Basa Basi Nyakitin; Waspada Bahaya Virus Wuhan (Cinta Dunia } \\
\text { Takut Mati); Harga Diri Nggak Bisa Dibeli; Budget Pas-Pasan Jiwa Sosialita } \\
\text { (BPJS); Utang Tak Dibayar Hidup Jadi Ambyar; Musuh Dibalik Senyuman; } \\
\text { Untung di Dunia Berkah Hingga Akhirat; Tahun Berlalu Nasib Masih Tak } \\
\text { Menentu; Islam Agama Yang Toleran. }\end{array}$ \\
\hline 7 & $\begin{array}{l}\text { lbadah dan Hukum } \\
\text { Syariat }\end{array}$ & $\begin{array}{l}\text { Hati-Hati Ibadah di Ujung Waktu; Apakah Ada Doa untuk Move On; } \\
\text { NgeRIBAnget; Wudhu Yang Membuka Pintu Surga; Viral Di Dunia Viral di } \\
\text { Langit; Kecanduan Ibadah; Membayar Lunas Sholat; Kenapa Sih Sholat Susah } \\
\text { Khusyu; Sholat Berjamaah Masih Salah?; Silakan Bermaksiat, Tapi lakukan } 5 \\
\text { Syarat ini Dulu; Cara Mensucikan Najis dan Hikmahnya; Waspada Pembatal } \\
\text { Sholat; Jalan Keluar Dari Neraka; Tahun Baruan Boleh Ga Sih?; Adakah Doa } \\
\text { Yang Tidak Dikabulkan? }\end{array}$ \\
\hline 8 & Akidah & $\begin{array}{l}\text { Allah Pun Juga Tertawa; Jika Besok Aku Mati; Hati Yang Mati; Peka dengan } \\
\text { Sinyal Peringatan Allah; Hewan-Hewan Pilihan Allah; Hura Hara Hari Peradilan; } \\
\text { Kesyirikan-Kesyirikan di Zaman Millenial. }\end{array}$ \\
\hline
\end{tabular}

Keempat, metode dakwahtainment. Untuk menghasilkan dakwah yang menghibur, maka metode yang digunakan oleh subjek dalam program Islam Itu Indah, di antaranya adalah dengan memasukkan selipan humor dalam isi ceramah, pembawaan yang khas seperti gaya bicara Ustaz Maulana atau dialek Betawi ala Ustazah Lulung, menggunakan pantun seperti yang dilakukan Ustaz Taufiqurahman, menggunakan teknik sulap ala Ustaz Koko Liem, dan sebagainya. Metode lain yang digunakan adalah dengan cerita inspiratif seperti kisah nabi atau sahabat, pembacaan murrotal Quran oleh Ustaz Syam, penayangan video pendek halhal yang viral di masyarakat dan berhubungan dengan tema. Hiburan lain dalam program Islam Itu Indah adalah kehadiran grup nasyid "Nash Indonesia" yang menampilkan lagu-lagu nasyid atau pop dibalut nasyid menyesuaikan dengan 
tema. Kehadiran bintang tamu dari kalangan selebritas, tidak hanya sekadar sebagai pendengar saja, tetapi mereka juga dilibatkan dalam proses acara, seperti diberi kesempatan untuk bertanya kepada ustaz/narasumber, juga ditanyai oleh host. Mengingat tema yang diangkat tidak lepas dari kehidupan sehari-hari, pertanyaanpertanyaan yang diajukan oleh host sedikit banyak mengulik kehidupan keseharian bintang tamu. Seperti pada episode 29 Januari 2020, dengan tema "Nikah Makin Lama Makin Romantis" menghadirkan bintang tamu Melki Bajaj dan istri yang ditanyai terkait kehidupan rumah tangga kedua pasangan tersebut. Menghadirkan bintang tamu dan info-info seputar bintang tamu, yang tentunya tetap dikaitkan dengan tema program, menjadi salah satu metode dakwahtainment dalam program Islam Itu Indah.

Kelima, media dakwahtainment. Bagi pemirsa di rumah maka televisi menjadi media dakwahtainment program Islam Itu Indah. Namun tidak terbatas pada televisi, sebab khalayak juga bisa menyaksikan program melalui kanal YouTube Islam Itu Indah, dan cuplikannya di Instagram. Sementara bagi pemirsa di studio maka medianya adalah tatap muka.

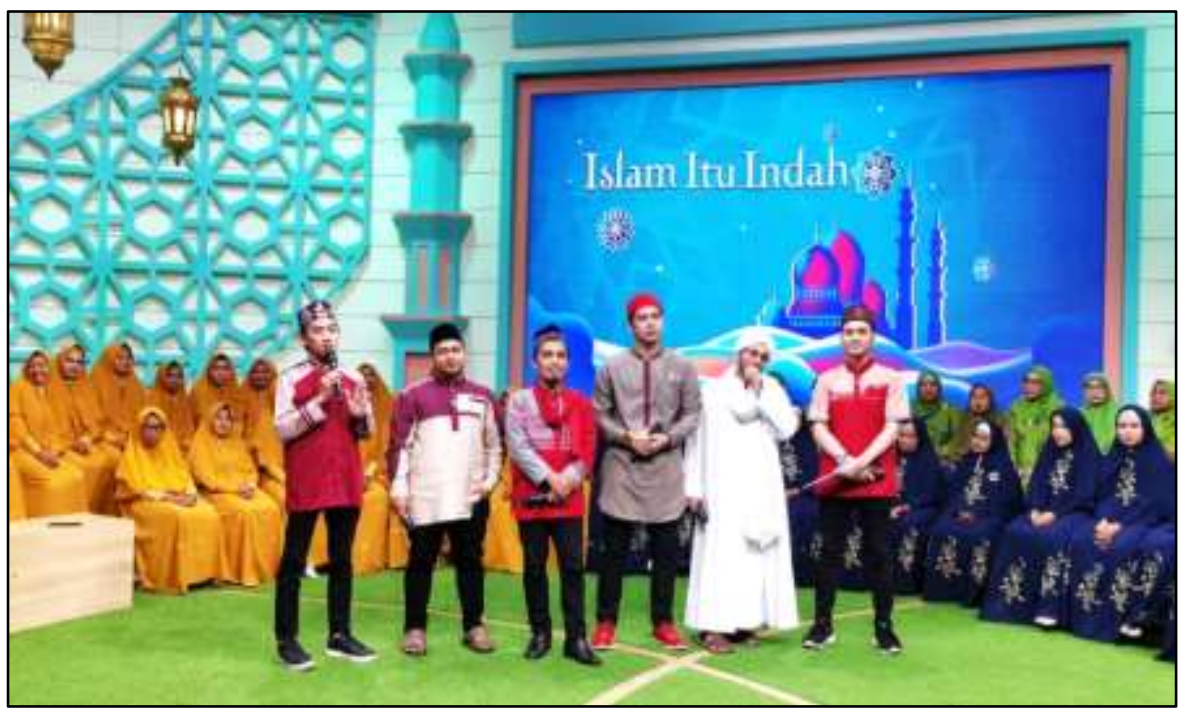

Gambar 2 - Para Narasumber, Bintang Tamu, dan Pembawa Acara Program Islam Itu Indah Episode 14 Februari 2020 dengan tema NgeRIBAnget. (Berurutan: Ustaz Syam; Ustaz M. Azhari Nasution; Ustaz Maulana; Bintang Tamu: Ricky Perdana; Habib Muhammad Syabab; dan Host Akhmad Fadli)

\section{Komodifikasi Program Dakwahtainment di Televisi Pendekatan Semiotik}

Tujuan pertama dari studi ini adalah untuk mengidentifikasi gejala komodifikasi dalam program dakwahtainment Islam Itu Indah. Gejala komodifikasi didekati dengan analisis teks secara semiotik. Pendekatan semiotik mengungkap struktur penanda, petanda, dan signifikasinya secara denotatif dan konotatif. Oleh karenanya tidak semua tanda yang muncul dalam tayangan Islam Itu
Indah dianalisis tetapi hanya yang relevan dengan tujuan studi didasarkan pada observasi selama tiga bulan. Komodifikasi dalam program dakwahtainment menyangkut komodifikasi konten, khalayak, tenaga kerja, dan nilai.

Pertama, komodifikasi konten dalam program Islam Itu Indah. Komodifikasi konten terkait isi pesan dalam komunikasi yang dibentuk atau dimodifikasi sedemikian rupa agar menjadi lebih menarik dan laku 
dijual. Program Islam Itu Indah adalah acara dakwah berformat talkshow, sehingga aspek komunikasi dominan di dalamnya. Pesan dalam komunikasi dakwah sejatinya adalah ajaran Islam yang mencakup seluruh aspek kehidupan dan membawa pada rahmatan li al-ālaminn. Melalui pesan dakwah diharapkan dapat memberikan pemahaman, kesadaran, dan bahkan perubahan sikap menjadi lebih baik. Komodifikasi konten dalam program Islam Itu Indah diidentifikasi melalui struktur tanda konten pesan yang ditampilkan dalam tagline, tema/judul materi, dan desain studio. Tagline "Jamaah... Oh Jamaah... Alhamdulillah," adalah penanda yang menjadi petanda bagi program Islam Itu Indah. Kalimat tersebut adalah kalimat sapaan yang biasa digunakan Ustaz Maulana dalam setiap ceramahnya jauh sebelum beliau menjadi narasumber program Islam Itu Indah. Signifikansi secara denotatif dalam istilah "jamaah" adalah merujuk pada mitra dakwah yang menjadi pendengar ceramah. Sedangkan "Alhamdulillah" adalah ucapan syukur atas keberkahan dari Allah sekaligus pujian kepada Allah. Makna konotatif kalimat tersebut, jika dikaitkan dengan gejala komodifikasi akan nampak bahwa kalimat tersebut telah menjadi suatu citra dan asosiasi merek. Artinya publik ketika mendengar kalimat tersebut akan tahu atau ingat dengan program Islam Itu Indah. Citra dan asosisasi merek yang kuat dalam ekuitas merek pemasaran produk, karena dengan itu akan bisa mendatangkan loyalitas pelanggan. ${ }^{54}$ Ujungnya keuntungan perusahaan dapat meningkat dan bertahan lama. Hal tersebut telah terbukti, bahwa program Islam Itu Indah dengan tagline-nya adalah salah satu program dakwahtainment yang bisa bertahan hingga sekarang di tengah situasi persaingan yang kompetitif.

\footnotetext{
${ }^{54}$ Durianto Darmadi, Sugiarto dan Lie Joko Budiman, Brand Equity Ten: Strategi Memimpin Pasar (Jakarta: Gramedia Pustaka Utama, 2004), 61.

55 "ISLAM ITU INDAH - Tips Keluar Dari Permasalahan Keuangan (19/12/19) Part1 - part4," YouTube Video, Islam Itu Indah Official, diakses 20 Juni 2020.
}

Struktur tanda dalam pilihan istilah yang dijadikan tema materi tiap episodenya juga dapat diidentifikasi sebagai gejala komodifikasi konten. Secara keseluruhan judul-judul tema materi tersebut adalah penanda akan apa yang disampaikan dan dibahas oleh para narasumber, host, dan bintang tamu. Signifikasi tahap pertama, dapat diperhatikan pada keseluruhan judul materi dalam tabel 1 . Sebagian besar menyajikan tema-tema seputar kehidupan sehari-hari seperti masalah rumah tangga, rezeki, jodoh, pendidikan anak, pergaulan sosial, dan lain-lain. Pilihan temanya berkutat pada masalah-masalah tersebut, sehingga relatif ada kemiripan atau persinggungan pembahasan antara beberapa episode.

Sebagai contoh pada edisi 19 Desember 2019 dengan tema "Tips Keluar dari Permasalahan Keuangan - Lakukan Hal Ini, Masalah Keuangan Keluarga Hilang!" ${ }^{55}$ Tema tersebut membahas masalah keuangan keluarga, spesifiknya yang dibahas adalah: (a) apakah benar bahwa keuangan dan harta dapat menjadi ujian sekaligus anugerah bagi keluarga; (b) hubungan antara menurunnya kondisi keuangan terhadap keharmonisan keluarga; (c) Bolehkah istri menentukan uang bulanan yang diberikan suaminya atau istri harus memiliki uang tambahan disamping uang bulanan; (d) faktor penyebab suami menjadi pelit dalam memberikan nafkah bulanan istri dan cara menghadapinya; (e) bagaimana dengan istri yang menuntut uang bulanan di luar batas kemampuan suaminya; (f) cara istri bersabar ketika keadaan ekonomi rumah tangga diuji dengan keterbatasan; (g) bagaimana agar suami menjadi dermawan kepada istri; (h)

Part 1: https://youtu.be/tqSrU9Qm-RM Part 2: https://youtu.be/ImWxhiP21Ww Part 3: https://youtu.be/iBTe_Ilpa7k

Part 4 : https://youtu.be/K1ZË|67MxdU 
bagaimana jika suami tidak memberi nafkah karena istrinya memiliki penghasilan lebih banyak. ${ }^{56}$ Sub-sub pembahasan tersebut mirip dengan beberapa tema seperti: "Perempuan Pahlawan Devisa Keluarga," "Bahagiain Istri Rezeki Tidak Berseri," "Rezeki Seret? Salah Siapa?" dan sebagainya. Data-data tersebut menunjukkan bahwa tema-tema materi dakwah yang disajikan berkutat pada masalah-masalah itu saja.

Agar menarik pemirsa, maka pilihan istilah dalam judul memainkan peran penting. Istilah-istilah yang digunakan adalah yang menarik, sedang viral, dan dikesankan praktis dan solutif. Dari situ signifikasi tahap kedua dapat diidentifikasi sebagai gejala komodifikasi konten pesan komunikasi. Memilih istilah-istilah sedemikian rupa agar menarik (laku dijual). Sebagai contoh dalam pemilihan istilah judul "Budget Pas-Pasan Jiwa Sosialita (BPJS)." BPJS (Badan Penyelenggara Jaminan Sosial) ${ }^{57}$ secara makna denotatif adalah lembaga pemerintah yang menyelenggarakan kegiatan jaminan sosial untuk masyarakat. Namun untuk kepentingan dakwahtainment BPJS diberi singkatan dan pemaknaan lain. Secara konotatif hal tersebut diangkat karena di masyarakat sedang marak perbincangan tentang kenaikan tarif BPJS, sehingga istilah itu sedang viral. Momen itulah yang kemudian digunakan, sehingga konten pesan telah mengalami komodifikasi. Demikian pula pada judul "Apakah Ada Doa untuk Move On?" dan "Utang Tak Dibayar Hidup Jadi Ambyar" 58 Istilah "move on" dan "ambyar" sedang trend belakangan ini, khususnya di media sosial dan generasi muda. Signifikasi istilah tersebut dipilih

56 Instagram @islamituindahttv 19 Desember 2019.https://www.Instagram.com/p/B6NORAXF8fJ/?i gshid=is6uxhc0d58w

57 Instagram @islamituindahttv, 24 Januari 2020, https://www.Instagram.com/p/B7ssX7jFZio/

58 Instagram @islamituindahttv, “Apakah Ada Doa Untuk Move On?" 19 Februari 2020, https://www.Instagram.com/p/B8v5Uuml4nv/ bukan sekadar bermakna realitasnya, tetapi juga untuk kebutuhan komodifikasi konten pesan dalam program.

Desain studio sebagaimana ditunjukkan pada gambar 2, mencirikan ornamen menara masjid, lampu-lampu khas Timur Tengah, dengan dominasi warna hijau. Selain itu studio juga dilengkapi dengan layar LCD besar, yang digunakan untuk melihat beberapa tayangan video viral, juga pertanyaan-pertanyaan audiens di Instagram. Desain studio dengan adalah penanda dan petanda sebagai konten komunikasi program kepada khalayak. Signifikasinya secara denotatif adalah sebagai tempat acara program dakwahtainment. Secara konotatif menyiratkan pesan acara keislaman yang menarik dan modern (simbol menara masjid, warna hijau, layar LCD, dan lain-lain). Dari perspektif komodifikasi, simbol-simbol tersebut diperlukan guna mendukung kemenarikan acara. Dengan demikian secara keseluruhan bisa diindikasikan adanya gejala komodifikasi pada konten pesan komunikasi pada program Islam Itu Indah dalam pilihan istilah dalam judul, tagline, dan didukung set desain studio.

Kedua, komodifikasi khalayak dalam program Islam Itu Indah. Komodifikasi khalayak terkait dengan banyaknya pemirsa yang menyaksikan suatu program yang diindikasikan dengan nilai rating dan sharing tayangan program. Berdasarkan data pada periode Oktober 2017, rating program Islam Itu Indah adalah 1,2 dan tingkat share 15,9.59 Untuk acara sejenis tingkat rating dan share program Islam Itu Indah adalah yang tertinggi. Tingkat rating dan share tersebut

"Utang Tak Dibayar Hidup jadi Ambyar" 23 Januari 2020 https://www.Instagram.com/p/B7qTFvalUzv/

59 Novi Andayani Praptiningsih dan Ami Kusuma Handayani, "Problematika Produksi Program Dakwah Religi Televisi Islam Itu Indah," Prosiding Seminar Nasional dan Kolokium vol. 1, no.1 (2017):113-128. 
linier dengan data jumlah produk yang mengisi slot iklan dalam program Islam Itu Indah. Berdasarkan data observasi, rata-rata terdapat jeda iklan 5-6 kali dengan durasi 56 menit, dengan jumlah produk iklan 15-17 jenis. Di antaranya adalah produk iklan sabun mandi, sampo, pencuci pakaian, pewangi pakaian, minuman, dan lain-lain. ${ }^{60}$ Dengan demikian dalam 90 menit tayangan program Islam Itu Indah, 25 - 30 menitnya dihabiskan untuk iklan. Jika diandaikan biaya iklan sekitar 15 juta per 30 detik, ${ }^{61}$ maka pemasukan yang didapatkan adalah 750-900 juta setiap episodenya.

Secara semiotik, komodifikasi khalayak dapat diindikasi melalui struktur tanda dalam busana muslim yang ditampilkan oleh para narasumber dan host, yang tidak lain adalah produk dari salah satu produsen baju muslim kenamaan di Indonesia. Sekalipun tidak disebutkan secara langsung oleh host, namun dengan mengamati baju dan logo, khalayak akan mudah mengetahui produk tersebut. Signifikasi tanda tersebut secara denotatif sebagai busana muslim yang bagus dan sesuai dengan kebutuhan program. Secara konotatif dapat dimaknai sebagai promosi produk busana muslim. Terlebih di akhir acara ditampilkan logo produsen busana tersebut. Tentu ada nilai jual yang harus dibayar oleh produsen atas tampilan tersebut. Keberadaan khalayak atau pemirsa di studio yang didominasi kelompok pengajian ibu-ibu dengan busana muslim yang seragam, secara denotatif adalah tanda bahwa mereka adalah jemaah yang menjadi mitra dakwah secara langsung. Namun secara konotatif dapat diinterpretasikan bahwa program ini menyasar khalayak

60 Observasi Siaran Program Islam Itu Indah di Trans TV, Januari 2020

61 Galih Conainthata, "Update Harga Pasang Iklan di Televisi Nasional," harga.we.id, 25 November 2019. https://harga.web.id/berapakah-harga-pasang-iklandi-televisi-ini-dia-jawabannya.info

62 Ustaz Maulana pernah membintangi iklan televisi dan radio untuk produk Telkomsel, dalam akun Instagramnya beberapa kali mempromosikan produk perangkat seluler @m_nur_maulana perempuan, khususnya ibu-ibu. Dengan demikian secara semiotik, jumlah iklan, keberadaaan simbol produk dalam busana, keseragaman busana pada jemaah studio, serta tingkat rating dan share yang tinggi dapat diindikasi telah terjadi komodifikasi khalayak.

Ketiga, komodifikasi tenaga kerja dalam program Islam Itu Indah. Tenaga kerja adalah penggerak produksi konten program televisi yang meliputi pekerja produksi, distribusi acara, dan pengisi acara. Komodifikasi tenaga kerja yang dianalisis difokuskan pada pengisi acara, yaitu ustaz/ustazah yang menjadi narasumber, para host, dan bintang tamu. Komodifikasi pengisi acara diindikasikan dengan pemilihan pengisi acara yang bisa menarik banyak khalayak untuk menyaksikan acara, sekalipun secara kapabilitas masih kurang. Dengan keadaan yang seperti itu, mereka dituntut untuk menyesuaikan dengan kebutuhan tayangan program.

Keberadaan pengisi acara dalam program Islam Itu Indah adalah penanda dan petanda yang memiliki signifikasi makna. Secara denotatif, keberadaan ustaz/ustazah sebagai narasumber tidak sebatas bermakna sebagai subjek dakwah tapi sekaligus sebagai tenaga kerja dalam proses produksi program televisi. Sebagian besar dari ustaz/ustazah tersebut lebih terkenal sebagai ustaz selebritas, sebab mereka sering tampil di televisi. Tidak sedikit dari mereka yang juga membintangi iklan, menjadi brand ambassador, bermain peran dalam sinetron atau film. ${ }^{62}$ Layaknya para

https://www.Instagram.com/p/B9Bb_aiJy84/; Ustazah Oki adalah pemain film dan sinetron "Ketika Cinta Bertasbih," Ustaz Riza pernah main sintron "Pesantren \& Rock $n$ Roll" dan dalam akun Instagramnya mempromosikan produk perawatan wajah pria dan makanan, @ustdzrizamuhammad https://www.Instagram.com/p/B_7CnD5BJ_z/ https://www.Instagram.com/p/B_KAJvZBOOC/; Ustazah Lulung dalam akun Instagramnya beberapa kali mempromosikan produk makanan dan busana muslim @lulungmanis https://www.Instagram.com/p/CCKq99LIXay/ 
selebritas, kehidupan pribadi mereka juga menjadi bahan infotainment televisi.

Jika diperhatikan setiap ustaz/ustazah yang tampil di Islam Itu Indah selalu memiliki ciri khas dan keunikan tersendiri, seperti Ustaz Maulana dengan gaya ceramahnya yang ekspresif dan lucu. Ustaz Syam merupakan ustaz muda dengan bacaan Quran yang merdu. Ustaz Koko Liem yang menggabungkan ceramah dengan kemampuan sulapnya. Ustazah Lulung dengan gaya ceramah dialek Betawi. Habib Usman bin Yahya yang merupakan suami dari artis dan acara presenter olahraga di televisi, Kartika Putri. Ustaz Abdul Kaafi adalah salah satu dai muda dengan wajah tampan dan jebolan ajang pencarian bakat dakwah AKSI Indosiar. Ustaz Riza yang juga pernah bermain sinetron dan menjadi duta merek sebuah produk, dan lain-lain. Secara sosiokultural dapat dipahami bahwa masyarakat Indonesia menyenangi gayagaya ceramah yang menarik, dan menghibur.

Sekalipun demikian secara kapabilitas keilmuan khususnya terkait keislaman, narasumber dalam program Islam Itu Indah adalah orang-orang yang memiliki kualifikasi yang memadai sebagai penceramah. Sebagai contoh Ustaz Nur Maulana adalah memang seorang dai yang telah aktif berdakwah sejak usia 14 tahun. Beliau juga lulusan Pesantren An-Nahdah di Makasar. ${ }^{63}$ Ustaz Syam adalah seorang Sarjana Sosial Islam (S.Sos.I.) jurusan dakwah, dan Sarjana Quran (S.Q.) lulusan Institut Perguruan Tinggi IImu AlQuran (PTIQ) Jakarta, yang saat ini sedang

63 Sulfianto, "Fenomena Dakwah Berbasis Religiotainment (Sebuah Analisis Semiotika Terhadap Siaran Islam Itu Indah Trans TV)" (Undergraduated thesis, Universitas Islam Negeri Alauddin Makassar, 2018), 37.

64 Santi Rizky, "10 Potret Ustadz Syam yang Gayanya Kekinian dan Millennial Banget," IDN Times, April 29, 2020.

https://www.idntimes.com/hype/entertainment/santi -rizki/potret-ustadz-syam-yang-gayanya-kekinian-danmillennial-banget-c1c2-1/10 menempuh kuliah S2 pada perguruan tinggi yang sama. ${ }^{64}$ Ustazah Lulung yang sering menjadi narasumber tamu adalah lulusan IKIP dan pesantren di Lombok, selain aktif berdakwah sejak lama, beliau juga pernah menjadi guru agama. ${ }^{65}$ Sedangkan Ustaz Riza Muhammad adalah lulusan sebuah pesantren di Bali, dan telah aktif berdakwah sejak keterlibatannya dalam kontes dai di salah satu stasiun televisi pada tahun 2005. ${ }^{66}$ Dengan demikian jika ditinjau dari riwayat pendidikan dan keilmuannya, narasumber yang menjadi dai dalam program Islam Itu Indah memiliki kapabilitas yang memadai. Sehingga dalam hal ini tidak terjadi "pemaksaaan" terhadap narasumber untuk menyampaikan atau melakukan suatu hal di luar kapabilitasnya.

Signifikasi semiotik keberadaan ustaz-ustaz tersebut yang tidak sekadar memiliki kapabilitas keilmuan, namun ada daya tarik dan keunikan dari segi gaya komunikasi, metode ceramah, dan kepopulerannya, maka secara konotatif dapat dimaknai pemilihan ustaz-ustaz tersebut sebagai bagian dari upaya komodifikasi tenaga kerja (pengisi acara) agar program yang dibuat bisa menarik banyak khalayak dan mendatangkan banyak iklan.

Demikian pula dengan host dan bintang tamu dari kalangan artis/selebritas yang memang merupakan tenaga kerja industri pertelevisian. Host dipilih bukan karena kapabilitas keilmuannya untuk mendampingi para ustaz/ustazah yang menjadi narasumber, namun yang utama memiliki daya tarik, dari segi penampilan,

\footnotetext{
65 Tomi Tresnady, "Kisah Ustadz Menangis Dibayar Rp 35 Ribu hingga Rp 30 Juta," Suara.com, modified Desember, 2015.

https://www.suara.com/entertainment/2015/12/06/ 095040/kisah-ustadz-menangis-dibayar-rp35-ribuhingga-dibayar-rp30-juta\#!

66 Rengga, "Ustad Riza Muhammad Tak Masalah Disebut Ustad Seleb," detik.com, modified July 8, 2014. https://m.detik.com/hot/hot-profile/d-

2630904/ustad-riza-muhammad-tak-masalah-disebutustad-seleb
} 
kemampuan komunikasinya dalam membawa acara, bisa mencairkan suasana, dan lain-lain. Oleh karena itu dipilih dari kalangan selebritas bukan akademisi atau praktisi dakwah yang notabene secara keilmuan lebih memadai untuk mendampingi narasumber ustaz/ustazah. Secara tidak langsung host dituntut untuk memahami materi-materi dakwah yang menjadi tema pembahasan karena ia nantinya akan memandu jalannya program. Dari sini mengindikasikan gejala komodifikasi tenaga kerja.

Bintang tamu juga dipilih sedemikian rupa untuk menambah daya tarik acara. Dari mereka yang sedang naik daun, viral atau jadi perbincangan publik, atau sisi-sisi lain yang sekiranya menarik untuk diulas dan dikaitkan dengan tema pembahasan tausiah. Sebagai contoh pada episode 8 Februari 2020 "Viral di Dunia dan Viral di Langit" 67 menghadirkan artis dan selebgram yang tengah viral yaitu Sintya Marisca. ${ }^{68}$ Sehariharinya Sintya Marisca tidak mengenakan jilbab, namanya menjadi viral karena aksi jogetnya di salah satu acara penyanyi legendaris Didi Kempot. ${ }^{69}$ Ketika dihadirkan acara Islam Itu Indah, tentu bukan untuk berjoget, tetapi untuk memenuhi kebutuhan tema acara yang berhubungan dengan sesuatu yang viral. Dalam kesempatan itu ia juga diharuskan untuk mengenakan jilbab guna menyesuaikan kebutuhan acara. Tuntutan-tuntutan yang demikian secara tidak langsung berupaya untuk mengoptimalisasi bintang tamu agar sesuai dengan kebutuhan acara, sehingga gejala komodifikasi terjadi.

Pemilihan dan keberadaan host dan bintang tamu adalah bagian dari struktur tanda pada

67 Islam Itu Indah Official, Youtube, ISLAM ITU INDAH Viral Di Dunia Viral Di Langit $(8 / 2 / 20)$

https://www.youtube.com/watch?v=bXUoYV8L67A

68 @sintyamariscahttps://uww.Instagram.com/sintyamarisca/?hl=en

69 Tantiya Nimas Nuraini, "Mengenal Sintya Marisca,

Cewek Cantik Viral Gara-Gara Joget Cendol Dawet Didi program Islam Itu Indah. Mereka dipilih dan dioptimalisasi untuk memenuhi kebutuhan acara agar menarik. Sebagai tanda keberadaan host dan bintang tamu memiliki signifikasi denotatif sebagai bagian dari tenaga kerja pada program, yang tentu ada kewajiban dan hak yang dimiliki. Terlepas dari itu, secara konotatif pemilihan dan keberadaan host dan bintang tamu dengan simbol-simbol yang ditampilkan (busana muslim, kesesuaian tema, dan lain-lain) dapat dimaknai sebagai gejala-gejala komodifikasi tenaga kerja.

Keempat, komodifikasi nilai agama dalam program Islam Itu Indah. Komodifikasi nilai agama Islam yang dimaksudkan adalah mengubah nilai-nilai agama Islam menjadi sesuatu yang dapat dijual, sehingga membawanya ke dalam transaksi pasar, oleh karenanya selera pasar menjadi pijakan utama dalam program. $\mathrm{Di}$ sinilah transformasi nilai agama menjadi sesuatu yang lebih sempit terjadi. Dengan analisis semiotik, pesan-pesan dakwah yang disampaikan dalam program Islam Itu Indah diidentifikasi sejauhmana transformasi itu terjadi.

Substansi pesan dakwah adalah ajaran Islam itu sendiri. Islam adalah petunjuk hidup, ajarannya melingkupi seluruh aspek kehidupan manusia, tidak hanya mengatur bagaimana berhubungan dengan Allah, namun juga kepada sesama manusia dan kepada lingkungan alam. Islam tidak hanya soal ibadah yang bersifat personal dan ritualistik, tetapi juga ibadah sosial, bagaimana berpikir ilmiah, mencari ilmu pengetahuan, tanggung jawab sosial dalam pengentasan kemiskinan, berumah tangga dengan baik, penegakan hukum dengan adil,

Kempot," merdeka.com, 13 Desember 2019, https://www.merdeka.com/trending/mengenalsintya-marisca-cewek-cantik-viral-gara-gara-jogetcendol-dawet-didi-kempot.html 
memilih pemimpin yang baik, pendidikan anak yang baik, dan sebagainya. Sehingga pesan dakwah mestinya bukan soal menuruti selera pasar. Bahwa memang kebutuhan dan karakteristik pasar menjadi pertimbangan dalam penyusunan materi dakwah. Namun dalam pesan dakwah ada nilai-nilai ideal yang harus disampaikan, tidak sekadar menuruti kebutuhan dan keinginan pasar. Sehingga logika pemasaran tidak bisa sepenuhnya diterapkan dalam dakwah. Apabila itu dipaksakan berpotensi terjadinya transformasi dan reduksi makna agama itu sendiri, dengan kata lain komodifikasi nilai-nilai agama terjadi.

Signifikasi tanda pada teks/istilah yang digunakan sebagai judul tema materi program Islam Itu Indah secara denotatif bermakna sebagai tema yang akan dibahas dalam tiap episodenya. Judul-judul tersebut mengacu pada permasalahan kehidupan sehari-hari seperti masalah keluarga, jodoh, rezeki, pergaulan sosial, ibadah ritual, dan sebagainya. Secara konotatif, teks-teks yang dipilih dapat dimaknai sebagai gejala komodifikasi nilai-nilai agama. Agama (Islam) dalam teks judul tersebut ditampilkan sederhana dan pragmatis. Sederhana yang dimaksud adalah kesannya nilai-nilai agama Islam hanya menyangkut masalah personal (privat) seperti masalah jodoh, rezeki, keluarga, ibadah salat, anak, dan lain-lain. Hampir semua judul tema berkutat pada masalah-masalah tersebut. Sedangkan pragmatis yang dimaksud kesannya nilai-nilai yang terkandung dalam pesan/materi dakwah langsung bisa menyelesaikan masalah. Padahal untuk penerapannya butuh proses penyesuaian. Contoh teksnya: "Lakukan Hal Ini, Masalah

70 "ISLAM ITU INDAH - Keutamaan Menjodohkan Orang Lain Part 3," Video YouTube, dikirim oleh "Islam Itu Indah Official," Februari 24, 2020 https://www.youtube.com/watch?v=Ta6BTbajmTQ 71 "ISLAM ITU INDAH - Suamiku Bayiku PART2" Video YouTube, dikirm oleh "Islam Itu Indah Official," Februari 2,2020 https://www.youtube.com/watch?v=xH7eGqEnx90
Keuangan Keluarga Hilang!" "Apakah Ada Doa untuk Move On" dan sebagainya. Memang kelebihannya dengan mengangkat tema yang sederhana dan pragmatis, membuat mad'uw merasa lebih dekat dengan tema dan memantik mereka untuk mau mendalami Islam. Suatu hal yang juga diperlukan guna keberhasilan dakwah.

Lebih lanjut dalam beberapa pembahasan dapat diidentifikasi secara semiotik terjadinya reduksi nilai-nilai keagamaan. Sebagai contoh pada episode "Keutamaan Menjodohkan Orang Lain" 70 dalam materi tersebut dijelaskan besarnya pahala menjadi mak comblang (menjodohkan) dalam Islam, dengan balasan bidadari dan istana di surga. Bahkan setiap langkah menjodohkan juga dihitung pahala. Dalam episode lain "Suamiku Bayiku" ${ }^{71}$ salah satunya dalam materi tersebut dijelaskan bahwa suami yang manja adalah sumber pahala. Pada episode "Viral di Dunia dan Viral di Langit"72 salah satunya dibahas "rahasia agar bisa viral di dunia dan viral di langit" yang isinya di antaranya dengan menjadi muazin, dan memberi kelonggaran pada orang yang berutang. Sebagai struktur tanda, signifikasi pesan tersebut secara konotatif dapat dimaknai sebagai penyederhanaan dan pragmatisme nilai-nilai agama Islam. Seolaholah individu muslim hanya dengan menjodohkan orang lain bisa mendapat balasan surga, atau memanjakan suaminya mendapatkan pahala besar. Dengan menjadi muazin dan memberi kelonggaran orang yang berutang bisa menjadi viral di dunia dan di langit.

Namun pola yang demikian juga memiliki kelebihan, di antaranya dengan penyajian

\footnotetext{
72 "ISLAM ITU INDAH - Viral Di Dunia Viral Di Langit PART2," Video YouTube, dikirim oleh "Islam Itu Indah Official," $\quad$ Februari 2020. https://www.youtube.com/watch?v=yfVzIWfny8o "ISLAM ITU INDAH - Viral Di Dunia Viral Di Langit PART3," Video YouTube, dikirim oleh "Islam Itu Indah Official," Februari 8, 2020. https://www.youtube.com/watch?v=UCbDcR5S3-o
} 
sederhana dan praktis akan mendorong seseorang untuk mudah memahami dan mudah mengamalkan. Terlebih pada masyarakat yang secara pemahaman keislaman masih minim, informasi-informasi tersebut dapat menjadi pelajaran baru. Memang jika dikaitkan dengan konteks sosiokultur masyarakat modern yang lekat dengan pragmatisme dan individualisme, maka nampak gejala-gejala komodifikasi nilai agama. Tidak bisa dipungkiri bahwa secara umum tema-tema seperti itulah yang dipandang lebih laku dijual. Inilah efek samping yang membahayakan dari proses komodifikasi nilai-nilai agama yang terjadi dalam program dakwahtainment.

\section{Efek Eksternalitas Dakwahtainment pada Umat Islam Indonesia}

Secara teoretis komodifikasi dalam kegiatan penyiaran televisi selalu menghasilkan efek eksternalitas. Efek eksternalitas tersebut bisa bernilai positif, negatif, dan atau keduanya. Untuk memahami efek eksternalitas yang dihasilkan dari siaran program Islam Itu Indah digunakan dua pendekatan, yaitu pendekatan logika sebab akibat dari proses komodifikasi di atas, dan pendekatan data empiris terkait efek yang dihasilkan oleh siaran tersebut.

Pertama, pendekatan logika sebab akibat proses komodifikasi program Islam Itu Indah di Trans TV. Dalam program Islam Itu Indah yang masuk dalam sistem penyiaran komersil, gejala komodifikasi diindikasi telah terjadi. Sebagai program siaran televisi, Islam Itu Indah berhasil menjadi tontonan yang selalu dinanti pemirsa. Bila berpijak pada identifikasi gejala komodifikasi yang terjadi, maka secara logika sebab akibat terdapat beberapa efek yang dihasilkan. Efek-efek tersebut dapat diklasifikasi secara pemahaman (kognitif), perasaan (afektif), dan sikap (konatif).

Secara umum efek pemahaman yang dihasilkan dari program dakwahtainment Islam Itu Indah adalah terkait dengan pemahaman tema atau materi dakwah yang disajikan. Sehingga bagi khalayak yang belum mengetahui hal tersebut akan membantu memberikan pemahaman baru. Sebagai contoh terkait tema "Emang Ada Mandi Khusus Buat Perempuan?" maka bagi kalangan perempuan yang belum mengetahui hal tersebut akan menjadi informasi baru. Namun karena secara keseluruhan tema-tema materi yang dibahas pada program tersebut yang lebih banyak berkutat pada masalah rumah tangga, jodoh, pergaulan sosial, ibadah ritual, dan sejenisnya maka pemahaman keagamaan tentang Islam hanya seputar masalahmasalah itu saja. Aspek-aspek lain dalam ajaran Islam yang tidak dibahas menjadi tidak dimengerti. Sehingga dikhawatirkan akan membentuk pemahaman bahwa ajaran Islam hanya seperti itu saja, yaitu menyangkut masalah personal dan kegiatan ritual semata. Sementara aspek sosial kemasyarakatan yang tidak banyak disinggung bisa dipandang bukan bagian dari ajaran Islam. Dengan program dakwahtainment yang demikian tentu akan sulit untuk menghasilkan pemahaman keislaman yang integral, hanya bersifat lebih informatif.

Secara afektif, pola dakwahtainment seperti program Islam Itu Indah bagi pemirsa secara umum dapat melahirkan perasaan-perasaan senang, bahagia, karena mendapat hiburan melalui gaya ceramah yang lucu dan unik, maupun bintang tamu yang dihadirkan. Jika melihat gaya ceramah Ustaz Maulana kebanyakan orang akan merasa terhibur, karena ada aspek humor yang disisipkan dalam ceramahnya. Belum lagi bahasa tubuh dan gaya bicaranya yang ekspresif. Di situlah 
memang kepiawaian Ustaz Maulana. Namun bagi pemirsa yang lebih konsen pada isi dakwah, barangkali akan merasa terganggu dengan bahasa tubuh dan gaya bicara Ustaz Maulana.

Sementara efek secara sikap dari komodifikasi program Islam Itu Indah dapat melahirkan dorongan dan perilaku untuk meniru dari khalayak program. Sikap meniru/imitasi tersebut bermacam-macam, di antaranya: meniru untuk bisa hadir seperti pemirsa di studio, meniru busana muslim yang dikenakan ustaz/ustazah maupun host. Bagi dai muda juga bisa meniru gaya ceramah yang ditampilkan oleh para ustaz/ustazah narasumber program. Beberapa bahkan mungkin bisa meniru konsumsi atau penggunaan produk-produk yang iklannya dibintangi oleh narasumber program. Secara sosiologis, efek imitasi tersebut adalah hal yang lumrah terjadi, dan diharapkan dalam proses komodifikasi, sebab dengan itu program akan dapat terus berjalan dan mendapatkan keuntungan.

Kedua, pendekatan data empiris terkait efek mengikuti tayangan Islam Itu Indah. Datadata tersebut didapatkan dari hasil penelitian dan beberapa pemberitaan terkait. Penelitian yang dimaksud adalah meneliti pengaruh, tanggapan, maupun persepsi menyaksikan program Islam Itu Indah. Hasil studi-studi tersebut dapat menjadi gambaran awal bagaimana efek eksternalitas terjadi dari menyaksikan program Islam Itu Indah. Berikut penjelasan ketiga studi tersebut:

Tabel 2 - Studi-Studi Terkait Efek Eksternalitas Mengikuti Program Islam Itu Indah

\begin{tabular}{|c|c|c|c|}
\hline No & Judul & Subjek & Hasil \\
\hline 1 & $\begin{array}{l}\text { Pengaruh Menonton } \\
\text { Program Islam Itu Indah } \\
\text { di Trans TV }(\mathrm{X}) \text { terhadap } \\
\text { Peningkatan } \\
\text { Pengetahuan } \\
\text { Keagamaan Masyarakat } \\
\text { di Desa Gondoharum } \\
\text { Kecamatan Pageruyung } \\
\text { Kabupaten Kendal (Y). } .^{73}\end{array}$ & $\begin{array}{l}\text { Masyarakat } \\
\text { Desa } \\
\text { Gondoharum } \\
\text { Kecamatan } \\
\text { Pageruyung } \\
\text { Kabupaten } \\
\text { Kendal }\end{array}$ & $\begin{array}{l}\text { Hipotesis menonton Program Islam Itu Indah di Trans } \\
\text { TV terhadap Peningkatan Pengetahuan Keagamaan } \\
\text { Masyarakat di desa Gondoharum Kecamatan } \\
\text { Pageruyung Kabupaten Kendal diterima, artinya } \\
\text { makin tinggi atau aktif menonton program Islam Itu } \\
\text { Indah di Trans TV, maka makin baik pula pengetahuan } \\
\text { keagamaan masyarakat di desa Gondoharum } \\
\text { kecamatan Pageruyung kabupaten Kendal. }\end{array}$ \\
\hline 2 & $\begin{array}{l}\text { Tanggapan Mahasiswa } \\
\text { Fakultas Dakwah dan } \\
\text { Komunikasi UIN } \\
\text { Walisongo terhadap } \\
\text { Dakwahtainment di } \\
\text { Televisi (Program Siaran, } \\
\text { "Islam Itu Indah" di } \\
\text { Trans TV)" }\end{array}$ & $\begin{array}{l}\text { Mahasiswa } \\
\text { Fakultas } \\
\text { Dakwah dan } \\
\text { Komunikasi } \\
\text { UIN } \\
\text { Walisongo }\end{array}$ & $\begin{array}{l}\text { Sebagian besar subjek menanggapi bahwa program } \\
\text { siaran "Islam Itu Indah"" di Trans TV menarik karena } \\
\text { cara penyampaian materi oleh Ustaz Maulana } \\
\text { tergolong unik, diselingi dengan candaan serta } \\
\text { mempunyai sisi entertainment. Sangat menarik untuk } \\
\text { ditonton di kalangan mahasiswa atau anak muda. }\end{array}$ \\
\hline 3 & $\begin{array}{l}\text { Persepsi anggota KPID } \\
\text { (Komisi Penyiaran Indonesia } \\
\text { Daerah) Jawa Tengah } \\
\text { tentang Dakwahtainment di } \\
\text { Televisi (studi program } \\
\text { Islam Itu Indah di Trans } \\
\text { TV) }^{75}\end{array}$ & $\begin{array}{l}\text { Anggota } \\
\text { KPID Jawa } \\
\text { Tengah }\end{array}$ & $\begin{array}{l}\text { Program dakwahtainment di televisi (Islam Itu Indah } \\
\text { di Trans TV) merupakan program yang sudah baik, } \\
\text { dengan metode ceramah yang dikolaborasikan } \\
\text { dengan jalannya acara dengan menghadirkan bintang } \\
\text { tamu sebagai mad'uw yang mengikuti jalannya acara. }\end{array}$ \\
\hline
\end{tabular}

73 Dian Lestari, ““”engaruh Menonton Program “Islam Itu Indah" di Trans TV Terhadap Peningkatan Pengetahuan Keagamaan Masyarakat di Desa Gondoharum Kec. Pageruyung Kab. Kendal" (Skripsi, IAIN Walisongo Semarang, 2011).

74 Jamilatul Jauharoh Umminur, "Tanggapan Mahasiswa Fakultas Dakwah dan Komunikasi UIN
Walisongo Terhadap Dakwahtainment di Televisi (Program Siaran "Islam Itu Indah" di TRANS TV)" (Undergraduated thesis, UIN Walisongo, 2015).

75 Ana Widiyawati, "Persepsi Anggota KPID Jawa Tengah Tentang Dakwahtainment di Televisi: Studi Program Islam Itu Indah di Trans TV" (Undergraduated thesis, UIN Walisongo, 2017). 
Berdasarkan hasil ketiga studi di atas dapat diketahui bahwa respon ketiga kelompok subjek yang diteliti secara umum adalah positif. Hal tersebut dapat menjadi gambaran awal bahwa terdapat efek eksternalitas yang bernilai positif dari tayangan program Islam Itu Indah. Tentu saja dengan catatan bahwa studi-studi di atas dilakukan pada subjek yang bersifat terbatas.

Dalam salah satu artikel jurnal yang terbit tahun 2017, berjudul "Analisis Isi Program Islam Itu Indah di Stasiun Trans TV," yang melakukan analisis isi pesan dakwah yang disampaikan Ustaz Maulana sebanyak tujuh episode dipilih secara acak. Dalam setiap episode, diuraikan dan dianalisis secara deskriptif baik dari sisi kelebihan (positif) maupun kekurangan (negatif) pada pesan dakwah. Secara keseluruhan dalam artikel disimpulkan bahwa Ustaz Maulana dalam beberapa hal kurang menguasai materi yang disampaikan, jawaban yang diberikan kadang kala tidak tuntas. Dari tujuh episode yang dianalisis, hampir di setiap episode banyak penjelasan-penjelasan yang kurang menyertakan dalil-dalil Al-Qur'an, hadis, maupun pendapat para ulama, pernah juga menyertakan dalil yang kurang tepat. ${ }^{76}$ Hasil studi tersebut bisa menjadi landasan untuk memberikan gambaran efek eksternalitas dari program Islam Itu Indah, di mana secara konten yang disajikan ternyata dipandang ada yang kurang, dan tidak tuntas. Hal tersebut tentu berefek kepada khalayak yang mengikuti program, pemahaman

76 Zamris Habib and Hardjito, "Analisis isi program Islam Itu Indah di Stasiun Trans TV," Misykat Al-Anwar Jurnal Kajian Islam dan Masyarakat, Vol.28, No.1 (2017). DOI : 10.31904/ma.v28i1.3833

$77 \mathrm{KPI}$, "Peringatan Tertulis Untuk Program Islam Itu Indah Trans TV," www.kpi.go.id/index.php/id/edaran-dan-

sanksi/34899-peringatan-tertulis-untuk-program-

siaran-islam-itu-indah-trans-tv

78 Nur Qolbi, "Ceramah Ustaz Syam Menuai Protes, KPI Peringatkan Trans TV," Tempo.co, modified Juli 19, 2017.

https://nasional.tempo.co/read/892799/ceramah- keagamaannya dalam aspek tertentu menjadi kurang dan tidak tuntas.

Dalam penelusuran beberapa pemberitaan terkait, diketahui bahwa program Islam Itu Indah telah mendapatkan beberapa kali peringatan dari Komisi Penyiaran Indonesia (KPI). Pada tanggal 31 Desember 2018, KPI mengeluarkan peringatan tertulis untuk program siaran Islam Itu Indah Trans TV. Isi peringatannya adalah adanya potensi pelanggaran pada progam edisi 9 Desember 2018 yang menampilkan wanita mengalami kesurupan. Muatan serupa juga tayang pada edisi 8 Desember 2018 dengan melibatkan pelajar. Hal tersebut melanggar Surat Edaran nomor no 481/K/KPI/31.2/09/2018 tanggal 5 September 2018 tentang Program Siaran Mistik, Horor, dan Supranatural di Lembaga Penyiaran Televisi. ${ }^{77}$ Pada 19 Juli 2017, situs tempo.co juga memberitakan peringatan $\mathrm{KPI}$ kepada Trans TV terkait program Islam Itu Indah pada edisi 15 Juli 2017 terkait isi ceramah Ustaz Syam, yang mengatakan bahwa salah satu nikmat yang ada di surga adalah pesta seks. Hal tersebut menuai protes dari warganet dan berpotensi menimbulkan kegaduhan publik. 78 Sebelumnya pada 2015, Ustaz Maulana juga pernah dipersoalkan dan dilaporkan ke polisi karena isi ceramah kontroversialnya yang menyampaikan bahwa kepemimpinan tidak perlu melihat latar belakang agama. ${ }^{79}$

Pemberitaan-pemberitaan di atas menunjukkan bahwa konten dakwah yang disampaikan ternyata juga ada yang menimbulkan kontra dari publik, bahkan

ustaz-syam-menuai-protes-kpi-peringatkantranstv/full\&view=ok

79 Aditia Saputra "Begini Isi Ceramah Ustad Maulana yang Dipersoalkan," Liputan 6.com, November 29, 2015. https://m.liputan6.com/showbiz/read/2377392/begini-isi-

ceramah-ustad-maulana-yang-dipersoalkan; Icha Rastika, "Ustaz Maulana Dilaporkan ke Polisi," Kompas.com, modified November 27. 2015. https://megapolitan.kompas.com/read/2015/11/27/13255141 /Ustaz.Maulana.Dilaporkan.ke.Polisi. 
beberapa kali mendapatkan peringatan dari $\mathrm{KPI}$. Jika dihubungkan dengan artikel jurnal sebelumnya yang melakukan analisis isi konten, maka pemberitaan tersebut makin menguatkan simpulan bahwa ada yang kurang dalam konten dakwah yang disajikan. Sebagai contoh pernyataan salah satu narasumber yang menyatakan bahwa salah satu nikmat yang ada di surga adalah 'Pesta Seks.' Istilah tersebut seolah mengerdilkan nikmat yang ada di surga, sehingga orang yang mengejar surga dikesankan orientasinya rendah. Dalam Al-Qur'an maupun hadis juga tidak pernah disebut yang demikian, sehingga tidak cukup alasan untuk menggunakan istilah tersebut. Hal tersebut dapat mengaburkan pemahaman.

Berdasarkan dua pendekatan di atas, maka dapat disimpulkan bahwa efek eksternalitas pada komodifikasi dakwahtainment Islam Itu Indah bernilai positif dan negatif. Positif karena informasi materi dakwah yang disampaikan dapat menambah pengetahuan dan wawasan bagi jemaah, khususnya yang belum mengetahui pada tema-tema tertentu. Selain itu dakwah yang dikombinasikan dengan hiburan menjadi menarik dan menghibur. Sementara efek negatif terkait efek pemahaman yang disinyalir tidak mendalam. Konten dakwah yang disajikan lebih banyak bercorak individualistis, sehingga mengakibatkan jemaah tidak utuh, dan minim metodologis dalam memahami Islam.

\section{Kesimpulan}

Berdasarkan analisis semiotik pada struktur tanda yang sering muncul dalam tayangan Islam Itu Indah dapat diidentifikasi terjadinya gejala komodifikasi. Studi ini mengidentifikasi komodifikasi konten komunikasi yang diindikasi melalui signifikasi istilah tagline yang digunakan, signifikasi pemilihan istilah pada judul tema materi. Pilihan tema tersebut disajikan melalui istilah-istilah yang unik, viral, dan menarik. Sekalipun sebenarnya secara tema pembahasan berkutat pada masalah itu-itu saja. Komodifikasi khalayak selain diidentifikasi melalui tingkat rating dan share program serta slot jumlah produk iklan, secara semiotik dapat dilihat dari analisis struktur tanda pada busana yang ditampilkan oleh narasumber dan host yang tidak terlepas dari penempatan produk untuk dipromosikan.

Gejala komodifikasi tenaga kerja diidentifikasi dari pemilihan dan keberadaan pengisi acara. Narasumber yang dipilih selalu yang memiliki ciri khas dan keunikan bisa menghibur, sehingga teknis ceramahnya bermacam-macam. Ada yang ekspresif, dengan humor, dengan sulap, dengan pantun, dan lain-lain. Pemilihan host dari kalangan artis dan bintang tamu adalah untuk menarik pemirsa. Komodifikasi nilainilai agama diidentifikasi melalui pesanpesan yang disampaikan oleh narasumber dalam tausiahnya. Ada indikasi-indikasi pragmatisme nilai-nilai Islam. Di sinilah kemudian Islam menjadi sempit maknanya. Tema-tema yang dibahas tidak terstruktur (terkurikulum) dan lebih banyak bersifat personal dan ritual. Namun kelebihannya tema yang dibahas ringan, dan dekat dengan persoalan kehidupan sehari-hari. Beberapa tema pembahasan juga dapat menjadi pengetahuan baru bagi masyarakat yang barangkali minim akses informasi selain dari media televisi. Dari uraian di atas dapat disimpulkan bahwa ada indikasi-indikasi komodifikasi secara konten, khalayak, tenaga kerja, dan nilai agama.

Efek eksternalitas program dakwahtainment Islam Itu Indah dalam tayangan sistem komersil ternyata memiliki efek eksternalitas positif dan negatif. Berbeda dengan pendapat Herman yang menyatakan bahwa dalam siaran komersil selalu bermuatan efek eksternal negatif. Hal 
tersebut dapat dipahami karena secara sosiologis tingkat pengetahuan keagamaan umat Islam di Indonesia tidaklah merata. Di daerah-daerah pelosok sangat mungkin minim informasi tentang agama Islam. Sehingga keberadaan tayangan program dakwahtainment dapat menjadi alternatif sumber informasi pengetahuan keagamaan. Namun efek negatif dari komodifikasi dalam tayangan dakwahtainment juga tidak sedikit. Agama seolah sekadar menjadi produk yang dijual untuk memenuhi kebutuhan pasar, sehingga perusahaan dapat memperoleh keuntungan ekonomi. Aspek substansi dari tujuan dakwah yaitu membangun pemahaman keagamaan yang benar dan utuh seolah terabaikan. Yang mana hal tersebut dapat dilakukan dengan memberikan penjelasan mendalam, disertai pendasaran metodologis, dan pengembangan daya nalar mad'uw. Sulit bagi publik, khususnya umat Islam jika hanya mengandalkan program dakwahtainment untuk bisa memahami Islam secara utuh.

Dakwahtainment sebagai bagian dari fenomena sosial masyarakat modern menjadi tantangan bagi para aktivis dakwah modern. Ada efek positif tetapi juga ada efek negatifnya. Saran berdasarkan kajian akademik ini khususnya untuk aktivis dakwah adalah bagaimana bisa masuk dalam sistem siaran dakwahtainment dan meminimalisir efek-efek negatif dari proses komodifikasi. Selain itu upaya-upaya untuk memberikan dakwah dengan cara-cara yang lebih terstruktur dan kreatif perlu dilakukan para aktivis dakwah, agar umat Islam memiliki berbagai sumber informasi keagamaan yang memadai.

\section{Bibliografi}

Adam, Aulia. "Wajah Acara TV: Ramai-Ramai Menayangkan Konten Dakwah Islami." Tirto.id. Modified Juni 6, 2018. https://tirto.id/wajah-acara-tv-ramai-ramai-menayangkan-konten-dakwah-islamicLKS.

Amila, Nuri. "Komodifikasi Agama Dibalik Ceramah Islam Itu Indah Ustad Maulana." Blogspot. Modified December 30, 2012. http://nouriesblog.blogspot.com/2012/12/komodifikasi-agama.html.

Amin, Samsul Munir. Ilmu Dakwah. Jakarta: Kreasindo Mediacita, 2009.

Ardianto, Elvinaro, Lukiati Komala, and Siti Karlinah. Komunikasi Massa Suatu Pengantar. Edisi Revisi. Bandung : Simbiosa Rekatama Media, 2007.

Atabik, Ahmad. "Prospek Dakwah Melalui Media Televisi." At-Tabsyir: Jurnal Komunikasi Penyiaran Islam $\begin{array}{llllll}\text { vol. } & 1, & \text { no. } & 2 & \text { (September } & \text { 2015): }\end{array}$ https://journal.iainkudus.ac.id/index.php/komunikasi/article/view/429.

Aziz, M. Ali. Ilmu Dakwah: Edisi Revisi. Jakarta: Prenadamedia Grup, 2016.

Barker, Chris. Cultural Studies: Teori dan Praktik. Terjemahan Nurhadi. Yogyakarta: Kreasi Wacana, 2006. Bible, Kierstin. "Book Review: Amusing Ourselves to Death - Public Discourse in the Age of Show Business." Unpublished (2017). https://www.researchgate.net/publication/316441068 Book Review Amusing Ourselves to Death Public Discourse in the Age of Show Business/link/58fe42 1da6fdcc8ed50c70aa/download.

Conainthata, Galih. "Update Harga Pasang Iklan di Televisi Nasional." harga.we.id. November, 2019. https://harga.web.id/berapakah-harga-pasang-ikan-di-televisi-ini-dia-jawabannya.info.

Darmadi, Durianto, Sugiarto dan Lie Joko Budiman. Brand Equity Ten: Strategi Memimpin Pasar. Jakarta: Gramedia Pustaka Utama, 2004.

Fiske, John. Introduction to Communication Studies. Second Edition. London: Routledge, 1990. 
Habib, Zamris dan Hardjito. "Analisis Isi Program Islam Itu Indah di Stasiun Trans TV." Misykat al-Anwar Jurnal Kajian Islam dan Masyarakat vol. 28, no. 1 (2017). DOI: 10.31904/ma.v28i1.3833.

Herman, Edward S. "The Externalities Effects of Commercial and Public Broadcasting." In P. Golding and G. Murdock. The Political Economy of the Media. Edward Elgar Publishing, 1997.

Ibrahim, Idi Subandy and Bachruddin Ali Akhmad. Komunikasi dan Komodifikasi: Mengkaji Media dan Budaya dalam Dinamika Globalisasi. Jakarta: Yayasan Pustaka Obor Indonesia, 2014.

Ira. "KPI Keluarkan Peringatan Untuk Program Islam Itu Indah." Kpi.go.id. Modified July, 2017. http://kpi.go.id/index.php/id/umum/38-dalam-negeri/34033-kpi-keluarkan-peringatan-untukprogram-siaran-islam-itu-indah?start=1017\&detail3=45.

Ismail, llyas and Prio Hotman. Filsafat Dakwah: Rekayasa Membangun Agama dan Peradaban Islam. Jakarta: Kencana, 2011.

Kittiarsa, Pattana, ed. Religious Commodifications in Asia: Marketing Gods. London: Routledge, 2008.

Komisi Penyiaran Indonesia. "Peringatan Tertulis Untuk Program Islam Itu Indah Trans TV." KPI.go.id. www.kpi.go.id/index.php/id/edaran-dan-sanksi/34899-peringatan-tertulis-untuk-programsiaran-islam-itu-indah-trans-tv.

Komisi Penyiaran Indonesia. "Hasil Survei KPI Kualitas Sinetron Makin Terpuruk." KPI.go.id. Modified Februari 4, 2017. https://www.kpi.go.id/index.php/lihat-terkini/38-dalam-negeri/33587-hasilsurvey-kpi-kualitas-sinetron-makin-terpuruk.

Lestari, Dian. "Pengaruh Menonton Program "Islam Itu Indah" di Trans TV Terhadap Peningkatan Pengetahuan Keagamaan Masyarakat di Desa Gondoharum Kec. Pageruyung Kab. Kendal." Skripsi, IAIN Walisongo Semarang, 2011. http://library.walisongo.ac.id/digilib/files/disk1/112/itptiain-gdl-dianlestar-5599-1071211037.pdf

Mahardani, Puspita Septi. "Strategi Kreatif Program "Islam Itu Indah" di TRANS TV dalam Mempertahankan Penonton Tahun 2016." Skripsi, Universitas Muhammadiyah Yogyakarta, 2016. http://repository.umy.ac.id/handle/123456789/7513.

Mankiewicz, Frank and Joel Swerdlow. Remote Control: Television and The Manipulation of American Life. New York: Ballantine Books, 1978.

Morissan. Jurnalistik Televisi Mutakhir. Jakarta: Kencana, 2010.

Mosco, Vincent. The Political Economy of Communication. London: SAGE Publication, 2009.

Muchtar, Khoiruddin and Faula Rahma Ghalia. "Respon Mahasiswa Terhadap Tayangan Dakwah Islamiyah Khazanah (Trans7) dan Damai Indonesiaku (TV One)." Interdisciplinary Journal of Communication vol. 3, no. 2 (2018): 147-174. DOI: 10.18326/inject.v3i2.147-174.

Murfianti, Fitri. "Komodifikasi Dakwah dalam Religiotainment di Stasiun Televisi Indonesia." Pendhapa: Jurnal ilmiah Pengkajian \& Penciptaan Seni Rupa dan Desain vol. 3, no. 1 (2012). https://jurnal.isiska.ac.id/index.php/pendhapa/article/view/1191.

Nuraini, Tantiya Nimas. "Mengenal Sintya Marisca, Cewek Cantik Viral Gara-Gara Joget Cendol Dawet Didi Kempot." merdeka.com. Desember 13, 2019, https://www.merdeka.com/trending/mengenal-sintya-marisca-cewek-cantik-viral-gara-garajoget-cendol-dawet-didi-kempot.html

Nurrokhim, M. "Analisis Brand Awareness dan Brand Association Acara Dakwah di Televisi." Jurnal Kajian dan Pengembangan Manajemen Dakwah, vol. 03, no. 02 (Desember 2013): 143-158.

Praptiningsih, Novi Andayani and Ami Kusuma Handayani. "Problematika Produksi Program Dakwah Religi Televisi Islam Itu Indah." Prosiding Seminar Nasional dan Kolokium vol. 1, no.1 (2017):113128

Polling Center, Laporan Naratif Propinsi-propinsi Aceh, DKI Jakarta, Jawa Timur, Kalimantan Timur, Sulawesi Selatandan Nusa Tenggara Timur - Survei Dasar terhadap Pemahaman, Persepsi dan Praktik Pemilih Terkait dengan Aspek Pemilu di Enam Target Propinsi (Polling Center: November 2013), 
asar\%20terhadap\%20KAP\%20pemilih\%20di\%20Enam\%20Propinsi Total\%206\%20Provinces 20 13.pdf.

Qolbi, Nur. "Ceramah Ustaz Syam Menuai Protes, KPI Peringatkan Trans TV." Tempo.co. Modified Juli 19, 2017. https://nasional.tempo.co/read/892799/ceramah-ustaz-syam-menuai-protes-kpi-peringatkantranstv/full\&view=ok.

Rastika, Icha. "Ustaz Maulana Dilaporkan ke Polisi." Kompas.com. Modified November 27, 2015. https://megapolitan.kompas.com/read/2015/11/27/13255141/Ustaz.Maulana.Dilaporkan.ke.Po lisi.

Rengga. "Ustad Riza Muhammad Tak Masalah Disebut Ustad Seleb." detik.com. Modified July 8, 2014 https://m.detik.com/hot/hot-profile/d-2630904/ustad-riza-muhammad-tak-masalah-disebutustad-seleb.

Rizki, Santi. "10 Potret Ustadz Syam yang Gayanya Kekinian dan Millennial Banget." IDN Times. April 29, 2020. https://www.idntimes.com/hype/entertainment/santi-rizki/potret-ustadz-syam-yanggayanya-kekinian-dan-millennial-banget-c1c2-1/10.

Rustandi, Ridwan. "Analisis Wacana Kritis Komodifikasi Dai dalam Program Televisi." Communicatus: Jurnal IImu Komunikasi vol. 2, no. 2 (2018): 197-222. DOI: 10.15575/cjik.v2i2.4949.

"Komodifikasi Dakwah Dalam Siaran Televisi: Analisis Wacana Kritis Program Religi "Islam itu indah" di Media Trans TV." Masters thesis, UIN Sunan Gunung Djati Bandung, 2017. http://digilib.uinsgd.ac.id/20192/

Saefulloh, Aris. "Dakwahtainment: Komodifikasi Industri Media di Balik Ayat Tuhan." Komunika: Jurnal Dakwah dan Komunikasi vol. 3, no. 2 (2009): 255-269. http://ejournal.iainpurwokerto.ac.id/index.php/komunika/article/download/129/103.

Saputra, Aditia. "Begini Isi Ceramah Ustad Maulana yang Dipersoalkan." Liputan6.com. Modified November 29, 2015, https://m.liputan6.com/showbiz/read/2377392/begini-isi-ceramah-ustadmaulana-yang-dipersoalkan

Sobur, Alex. Analisis Teks Media Suatu Pengantar untuk Analisis Wacana, Analisis Semiotik, dan Analisis Framing. Bandung: Remaja Rosdakarya, 2009.

Sofjan, Dicky with Mega Hidayati. Religion and Television in Indonesia Ethics Surrounding Dakwahtainment. Geneva: Globethics.net, 2013.

Sulfianto. "Fenomena Dakwah Berbasis Religiotainment (Sebuah Analisis Semiotika Terhadap Siaran Islam Itu Indah Trans TV)." Undergraduated thesis, Universitas Islam Negeri Alauddin Makassar, 2018. http://repositori.uin-alauddin.ac.id/10530/

Suyanto, Bagong. Sosiologi Ekonomi: Kapitalisme dan Konsumsi di Era Masyarakat Post-Modernisme. Jakarta: Kencana, 2013.

Tresnady, Tomi. "Kisah Ustadz Menangis Dibayar Rp 35 Ribu hingga Rp 30 Juta." Suara.com. Modified Desember, 2015. https:/www.suara.com/entertainment/2015/12/06/095040/kisah-ustadz-menangisdibayar-rp35-ribu-hingga-dibayar-rp30-juta\#!

Trans TV. "Islam Itu Indah." Transtv.co.id. Januari, 2020. www.transtv.co.id/program/28/islam-itu-indah. Umminur, Jamilatul Jauharoh. "Tanggapan Mahasiswa Fakultas Dakwah dan Komunikasi UIN Walisongo Terhadap Dakwahtainment di Televisi (Program Siaran "Islam Itu Indah" di TRANS TV)." Undergraduated thesis, UIN Walisongo, 2015. http://eprints.walisongo.ac.id/4768/

Widiyawati, Ana. "Persepsi Anggota KPID Jawa Tengah Tentang Dakwahtainment di Televisi: Studi Program Islam Itu Indah di Trans TV." Undergraduated thesis, UIN Walisongo, 2017. http://eprints.walisongo.ac.id/8474/

Zoest, Aart van. "Interpretasi dan Semiotika" dalam Sudjiman P. dan Aart van Zoest (ed.). Serba-Serbi Semiotika. Jakarta: Gramedia Pustaka Utama, 1996. 